\title{
Insight on Solution Plasma in Aqueous Solution and Their Application in Modification of Chitin and Chitosan
}

\author{
Chayanaphat Chokradjaroen ${ }^{1}$, Jiangqi Niu ${ }^{1}$, Gasidit Panomsuwan ${ }^{2}$ (D) and Nagahiro Saito ${ }^{1,3,4,5, *}$ \\ 1 Department of Chemical Systems Engineering, Graduate School of Engineering, Nagoya University, \\ Nagoya 464-8603, Japan; eig@sp.material.nagoya-u.ac.jp (C.C.); niu@sp.material.nagoya-u.ac.jp (J.N.) \\ 2 Department of Materials Engineering, Faculty of Engineering, Kasetsart University, Bangkok 10900, Thailand; \\ gasidit.p@ku.ac.th \\ 3 Conjoint Research Laboratory in Nagoya University, Shinshu University, Nagoya 464-8603, Japan \\ 4 Open Innovation Platform with Enterprises, Research Institute and Academia (OPERA), Japan Science and \\ Technology Corporation (JST), Nagoya 464-8603, Japan \\ 5 Strategic International Collaborative Research Program (SICORP), Japan Science and Technology \\ Corporation (JST), Nagoya 464-8603, Japan \\ * Correspondence: hiro@sp.material.nagoya-u.ac.jp
}

Citation: Chokradjaroen, C.; Niu, J.; Panomsuwan, G.; Saito, N. Insight on Solution Plasma in Aqueous Solution and Their Application in Modification of Chitin and Chitosan. Int. J. Mol. Sci. 2021, 22, 4308. https://doi.org/ 10.3390/ijms22094308

Academic Editor: Akikazu Sakudo

Received: 30 March 2021

Accepted: 17 April 2021

Published: 21 April 2021

Publisher's Note: MDPI stays neutral with regard to jurisdictional claims in published maps and institutional affiliations.

Copyright: (c) 2021 by the authors. Licensee MDPI, Basel, Switzerland. This article is an open access article distributed under the terms and conditions of the Creative Commons Attribution (CC BY) license (https:/ / creativecommons.org/licenses/by/ $4.0 /)$.

\begin{abstract}
Sustainability and environmental concerns have persuaded researchers to explore renewable materials, such as nature-derived polysaccharides, and add value by changing chemical structures with the aim to possess specific properties, like biological properties. Meanwhile, finding methods and strategies that can lower hazardous chemicals, simplify production steps, reduce time consumption, and acquire high-purified products is an important task that requires attention. To break through these issues, electrical discharging in aqueous solutions at atmospheric pressure and room temperature, referred to as the "solution plasma process", has been introduced as a novel process for modification of nature-derived polysaccharides like chitin and chitosan. This review reveals insight into the electrical discharge in aqueous solutions and scientific progress on their application in a modification of chitin and chitosan, including degradation and deacetylation. The influencing parameters in the plasma process are intensively explained in order to provide a guideline for the modification of not only chitin and chitosan but also other nature-derived polysaccharides, aiming to address economic aspects and environmental concerns.
\end{abstract}

Keywords: solution plasma process; aqueous solutions; chitin; chitosan; degradation; deacetylation

\section{Introduction}

In physics and chemistry, plasma is fundamentally defined as one of the four states of matter. Solid, liquid, and gas states are more common on the earth due to the atmospheric condition, whereas the plasma state dominantly exists in the universe (>99\%) (e.g., the sun, nebulae, etc.) [1]. Nevertheless, plasma can be artificially formed in the earth by giving sufficient thermal or electric energy supply, which ionizes the neutral gases to a quasi-neutral ionized gas [2]. The ionized gas is composed of negative and positive ions, free electrons, excited molecules, and excited atoms and molecules, as well as the emission of ultraviolet (UV) and high electric field [3]. Artificial plasma is classified as (i) thermal equilibrium plasma and (ii) non-thermal equilibrium plasma [4,5]. Thermal equilibrium plasma can be generated by a strong electrical power and, usually, under gas pressure of more than $5 \mathrm{kPa}$. Its gas and electron temperatures are nearly equal. On the other hand, in non-thermal equilibrium plasma, the gas temperature is lower than the electron temperature [4]. Non-thermal equilibrium plasma can be induced by giving sufficient energy under a vacuum system; however, it can also be generated under an atmospheric pressure environment by applying transient electrical or electrostatic discharges. Consequently, the non-thermal equilibrium plasma has offered several potential 
applications. Artificial plasmas in the gas phase are predominantly investigated under a wide range of operating pressures, including both vacuum and atmospheric conditions, and temperatures. A variety of gases (e.g., $\mathrm{Ar}, \mathrm{N}_{2}, \mathrm{O}_{2}, \mathrm{H}_{2}$, and mixtures) is applied to generate the plasmas depending on the purposes [6-8]. Even though plasma is theoretically mentioned as ionized gases, plasma can be in solid form (i.e., the formation of plasmon which is induced by the collective oscillation of free electrons moving around a lattice point) and liquid form (i.e., the generation of plasma in liquid, such as a pulsed electrical discharge in liquids) $[4,9,10]$. In the same manner, as the plasmas in the gas phase, plasma can be directly generated in the liquid phase by providing a sufficiently high electric field on the electrodes, leading to the electric breakdown of liquids. Over the past several years, the liquid-phase plasmas have been developed, along with the gas-phase plasmas. The liquid-phase plasmas have been mainly focused as a technology for wastewater treatment and water purification, owing to their ability to induce an effective production of reactive species, for example, hydroxyl radical $\left({ }^{\bullet} \mathrm{OH}\right)$, superoxide anion $\left(\mathrm{O}_{2}{ }^{-}\right)$, and hydrogen peroxide $\left(\mathrm{H}_{2} \mathrm{O}_{2}\right)[4,11,12]$. These reactive species can strongly oxidize and decompose organic pollutions and bacteria in water $[12,13]$. Recently, as the plasma technology being developed, the liquid-phase plasmas have been expanded and utilized for the synthesis and modification of various materials, such as noble-metal nanoparticles $[13,14]$, metal oxides [15,16], carbon materials [17-20], and natural polysaccharides [21,22]. Articles on the modification of natural polysaccharides, including chitin, chitosan, cellulose, alginate, mushroom polysaccharide, and starch, by liquid-phase plasma have been rapidly published in the past decade (Figure 1), which can imply the growth of the liquid-phase plasma in this field.

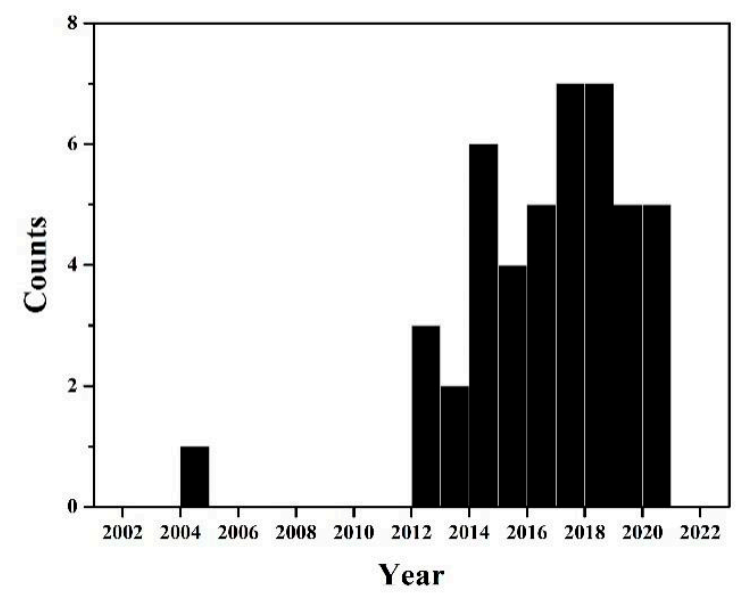

Figure 1. The number of articles relating to the modification of chitin and chitosan by liquid-phase plasma (data are shown in Supplementary Materials).

In this review, the insight into the plasmas in the liquid phase, mainly focused on an aqueous solution, is provided. The plasma technology called "solution plasma process (SPP)" will be dominantly explained. The discussion of recent development on the modification of chitin and chitosan, especially degradation, using the SPP will be given as examples. Modification techniques, reaction mechanisms, and changes in the properties of chitin and chitosan will be explained. In comparison with other existing methods, today, the modification of chitin and chitosan by the SPP is still at an early stage of development. The summary of relevant publications from the recent past to the present will provide benefits and a useful guideline for the researchers in the related fields to achieve the ecologically friendly and efficient method for the modification of chitin and chitosan. In addition, the remaining challenge and future trend of SPP technology in the field of not only chitin and chitosan but also other natural polysaccharides are also discussed to motivate future studies. 


\section{Solution Plasma Process (SPP): Chemistry and Influencing Parameters}

Electrode geometric construction and phase patterns of liquid-phase plasmas can be categorized into four groups: (1) direct electrical discharge between two electrodes [23], (2) contact electrical discharge between electrodes and the surface of the surrounding electrolyte, (3) miscible electrical discharge with external gas injection, and (4) special excitation electrical discharge (i.e., radio frequency, microwave irradiation or laser ablation). In this section, we will discuss on the direct discharge between two electrodes under the liquid-phase, which are presented by various terms. For example, submerged liquid plasma (wire-to-plate configuration using direct current) [24,25], pulsed plasma in liquid (rod-to-rod configuration, using pulsed voltage) [23], and solution plasma (pin-to-pin and wire-to-plate configurations, bipolar pulsed voltage) [26,27]. Apparently, these terms are assigned following their experimental setup, electrical power source, and electrodes configuration. Henceforward, the solution plasma process (SPP) with pin-to-pin electrode configuration will be described. SPP with pin-to-pin electrode configuration was firstly proposed by Takai and Saito's group [13,28]. In the SPP, the plasma is directly discharged between a pair of electrodes submerged under liquids at a short distance $(0.2-1 \mathrm{~mm})$, depending on its application, as shown in Figure 2. The power supplies are bipolar-pulsed high voltage supply. The use of pulsed voltage could reduce the current of the discharge. To a certain extent, it reduced the possibility of arc discharge due to thermal ion emission from the electrode and enhanced the number of carriers generated by secondary electron emission, thus enhancing the stability of discharge occurrence. Most studies using the SPP focus on the processing conditions and the properties and performance of the obtained products. The physical and chemical reactions occurring in the SPP are complex and rarely reported. Here, a brief explanation of the electrical discharge under an aqueous solution (e.g., electrical breakdown, formation of reactive species, and influencing factors) in the SPP is provided.
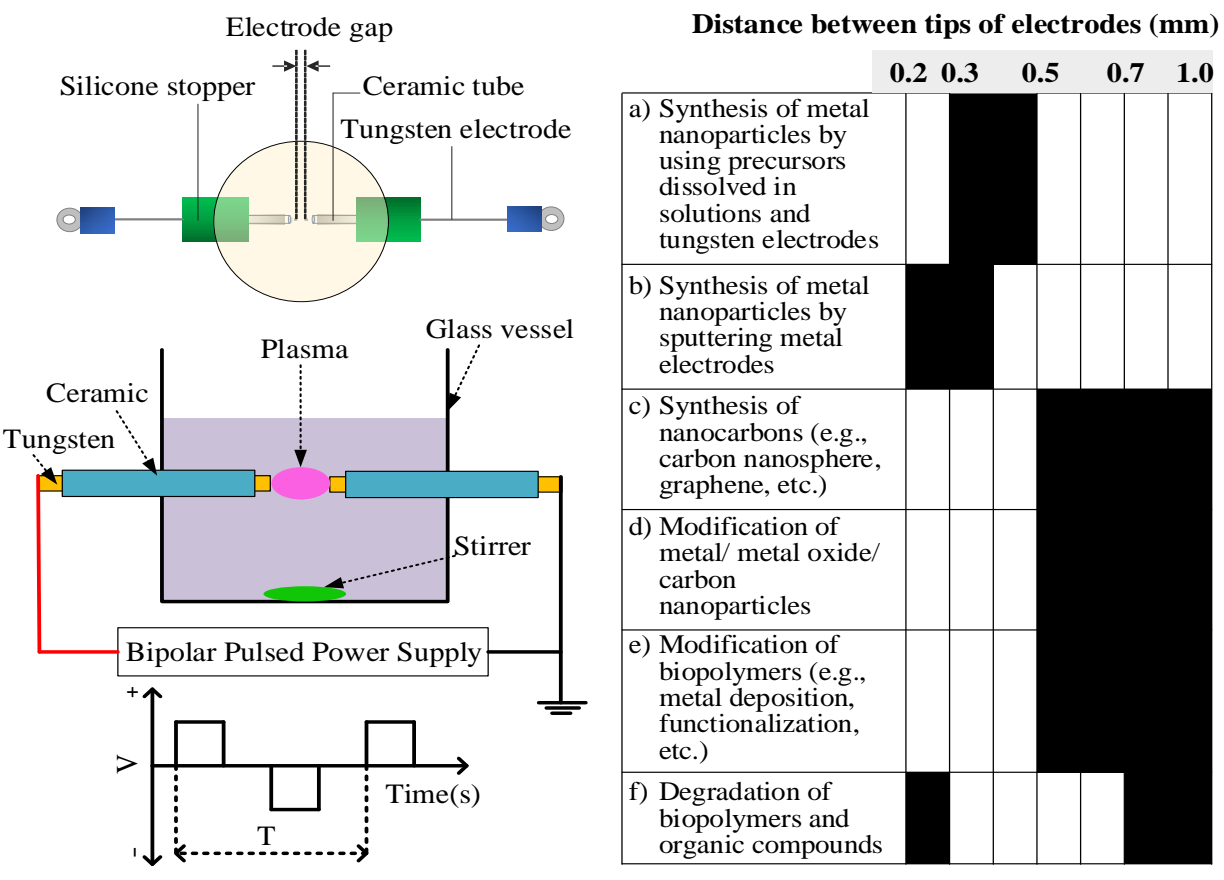

Figure 2. Schematic illustration of the SPP with pin-to-pin electrode configuration and its application with different distances between electrodes: (a) [14,29,30], (b) [31,32], (c) [27,33-35], (d) [36-38], (e) $[15,22]$, and (f) [39-42].

\subsection{Electrical Breakdown}

In chemical physics, the difference between gas and liquid phases is the molecular density. The difference in molecular density causes different insulation to withstand capability, high collision frequency and energy dissipation rate, and low electron mobility 
in liquids. Therefore, the plasma chemistry in gas and liquid phases is significantly different. The physical mechanism of gas-phase plasma can be explained based on the electron avalanche [43], which is a process that free electrons in the medium are strongly accelerated by an electric field, resulting in the collision with other atoms or molecules and then ionization. However, the electron avalanche can rarely occur in the liquid mediums because liquids usually have high molecular density, low mobility of charges, and recombination rate. However, as mentioned above, the plasmas in the liquid phase can be carried. The explanation was previously clearly given by Saito et al. in 2008 [44]. The liquid (e.g., aqueous solutions) near the electrode tips turn to gas or the formation of bubbles due to Joule heating, which causes solution vapor and electrolysis, resulting in gases such as $\mathrm{H}_{2}$ and $\mathrm{O}_{2}$. When the bubble is formed, the electron avalanche is produced in bubbles. The electrical break down is developed inside the bubbles and then formed as the plasma channel, which is kind of like "unzipping". The electrical breakdown can be controlled by the injection of more electrons into the ionization field in the bubble. Heo et al. revealed the current-voltage waveform by low-pass filter circuits, which could reduce noise signals as compared to that of the conventional circuits when the bipolar pulsed voltage was applied [45]. The stages of the applied voltages, breakdown, and plasma generation in the solution plasma process are also proposed in Figure 3.

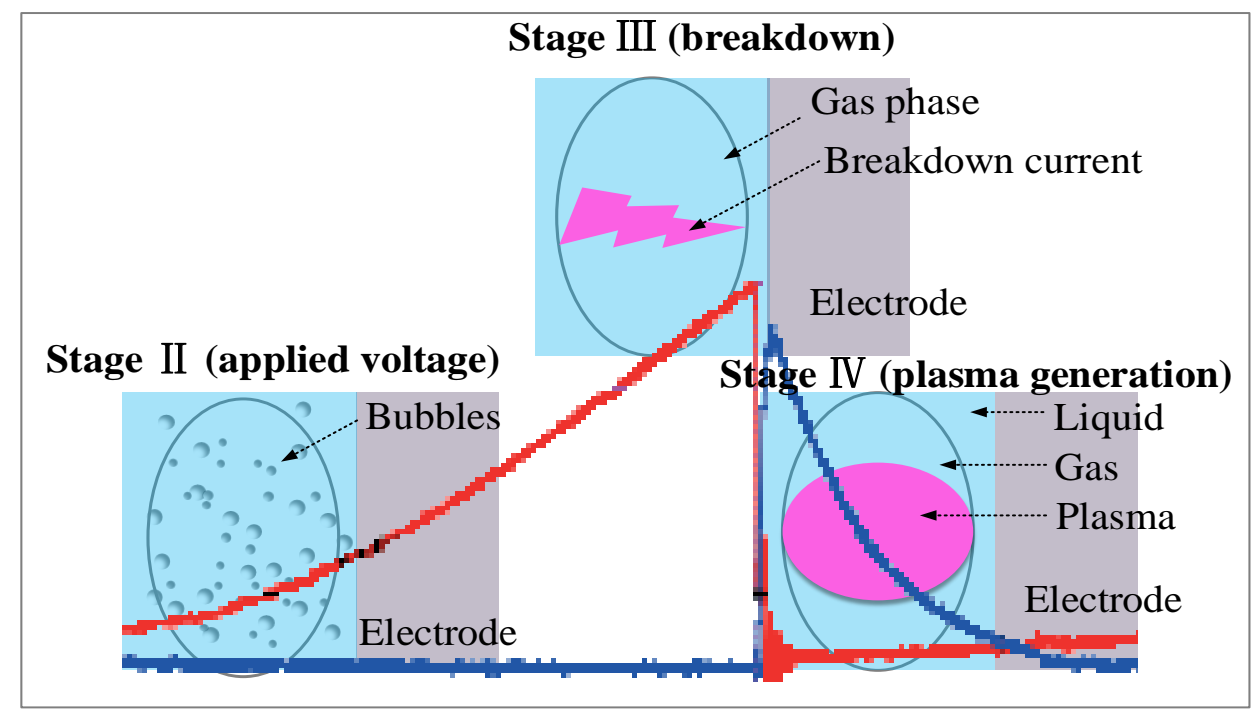

Figure 3. Schematic diagrams of the applied voltage, breakdown, and plasma generation stages in the SPP with the background of the current and voltage waveforms obtained by low-pass filter circuits [45].

Besides, the plasma discharges can be altered in different fluids to induce ionization, accelerate ions, and multiply the initial seed of electrons into the electron avalanche. The breakdown depends on the dipole moment of the fluids, including the dielectric behavior, ionization potential, band gap, and dipole moment $[4,44]$. For example, in water, the electrical discharge requires a large electric field $(67-70 \mathrm{MV} / \mathrm{m})$, while benzene requires a much higher energy field for the breakdown due to its higher dielectric strength (163 MV/m).

\subsection{Formation of Reactive Species}

Considering how the SPP can be used to modify chitin and chitosan, the plasmas in aqueous solutions or water plays a key role because almost all modifying processes for chitin and chitosan have been reported in aqueous solutions [46-49]. Several reactive species are generated when the electrical discharge is carried in water through molecules collision, mass transfer, vaporization, sputtering, and ultra-violet (UV) [44]. Many previous studies demonstrated that both short-lived reactive species (e.g., hydroxyl radical $\left({ }^{\bullet} \mathrm{OH}\right)$ and hydrogen radical $\left({ }^{\bullet} \mathrm{H}\right)$, superoxide $\left(\mathrm{O}_{2}^{-}\right)$) and long-lived reactive species (e.g., hydro- 
gen peroxide $\left(\mathrm{H}_{2} \mathrm{O}_{2}\right)$, ozone $\left.\left(\mathrm{O}_{3}\right)\right)$ are continuously formed and further reacted during the activation of water by the electrical discharge without the addition of a catalyst or chemical agents [50,51]. Figure 4 reveals the optical emission spectrum (OES) of reactive species generated in water during the SPP, which was measured in our research group. The short-lived reactive species, like ${ }^{\bullet} \mathrm{OH}$ and ${ }^{\bullet} \mathrm{H}$, are firstly generated from the main reaction via electron impact dissociation and continuous collision of reactive species to surrounding molecules, as shown below in Equation (1) [52]. The activity of ${ }^{\bullet} \mathrm{OH}$ and $\bullet \mathrm{H}$, is found to initiate and prolong modification reactions of chitin and chitosan, such as deacetylation, degradation, and altering the crystal structure, in not only plasma treatment but also in other methods, such as oxidative degradation [53]. Subsequently, hydrogen peroxide $\left(\mathrm{H}_{2} \mathrm{O}_{2}\right)$, the most common long-lived reactive species in the plasma-activated water, is formed via the recombination of ${ }^{\bullet} \mathrm{OH}$, as shown in Equation (12). In addition, in the water, there are dissolved oxygen molecules that can also be excited or ionized to reactive oxygen species (ROS), such as exited atomic oxygen $\left(\mathrm{O}\left({ }^{1} \mathrm{D}\right)\right.$ or $\left.\mathrm{O}_{\mathrm{I}}\right)$ and triplet ground-state atomic oxygen $\left(\mathrm{O}\left({ }^{3} \mathrm{P}\right)\right)$, singlet oxygen $\left({ }^{1} \mathrm{O}_{2}\right)$, and triplet oxygen $\left({ }^{3} \mathrm{O}_{2}\right) \cdot \mathrm{H}_{2} \mathrm{O}_{2}$ and these ROS also evidently contribute to the formation of ${ }^{\bullet} \mathrm{OH}[51,52]$.

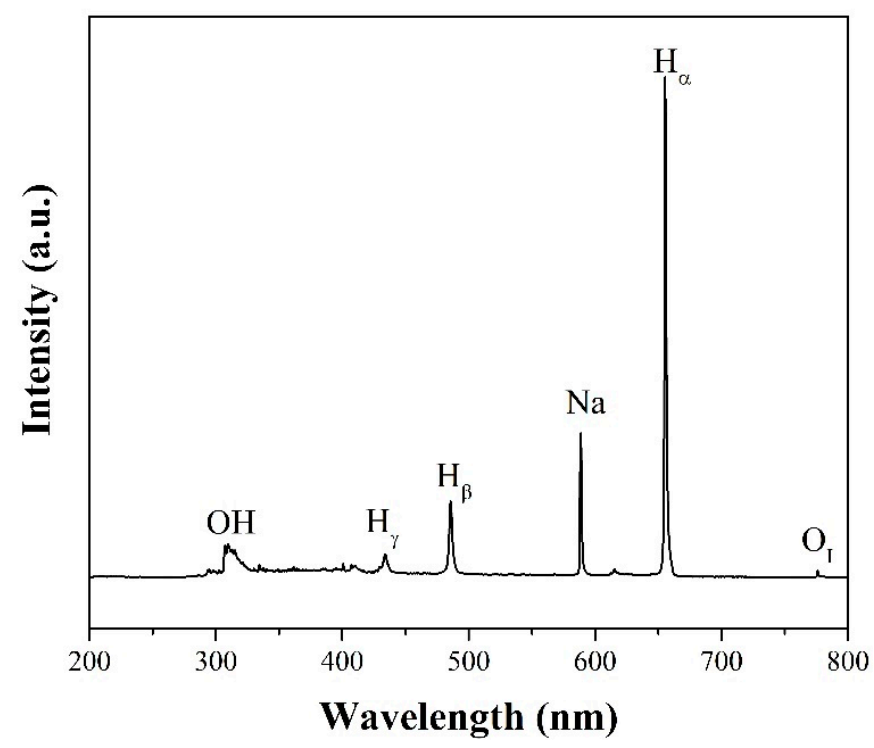

Figure 4. Optical emission spectrum (OES) of reactive species generated in water; its conductivity adjusted by $\mathrm{NaCl}$ at a concentration of $0.02 \mathrm{M}$ during the SPP.

The reactions revealing the possible formation of ${ }^{\bullet} \mathrm{OH}, \bullet \mathrm{H}_{,} \mathrm{H}_{2} \mathrm{O}_{2}$, and excited $\mathrm{O}$ are shown below [51,52]:

$$
\begin{gathered}
\mathrm{e}^{-}+\mathrm{H}_{2} \mathrm{O} \rightarrow \cdot \mathrm{OH}+{ }^{\bullet} \mathrm{H}+\mathrm{e}^{-} \text {(Ionization of water molecule by plasma discharge) } \\
\mathrm{e}^{-}+\mathrm{H}_{2} \mathrm{O} \rightarrow \mathrm{H}_{2} \mathrm{O}^{*}+\mathrm{e}^{-} \text {(Excitation of water molecule by plasma discharge) } \\
\mathrm{e}^{-}+\mathrm{M} \rightarrow \mathrm{M}^{*}+\mathrm{e}^{-} \text {(Sputtering of metal atom to excited metal atom) } \\
\mathrm{M}^{*}+\mathrm{H}_{2} \mathrm{O} \rightarrow{ }^{\bullet} \mathrm{OH}+{ }^{\bullet} \mathrm{H}+\mathrm{M} \\
\mathrm{e}^{-}+\mathrm{O}_{2} \rightarrow \mathrm{O}\left({ }^{3} \mathrm{P}\right)+\mathrm{O}\left({ }^{1} \mathrm{D}\right)+\mathrm{e}^{-}\left(\text {Ionization of } \mathrm{O}_{2}\right. \text { molecule by plasma discharge) } \\
\mathrm{O}\left({ }^{1} \mathrm{D}\right)+\mathrm{H}_{2} \mathrm{O} \rightarrow \bullet \mathrm{OH}+{ }^{\bullet} \mathrm{OH} \\
\cdot \mathrm{H}+\mathrm{O}_{2} \rightarrow{ }^{\bullet} \mathrm{OH}+\mathrm{O} \\
\mathrm{O}+\mathrm{O} \rightarrow \mathrm{O}_{2} \\
\mathrm{UV}+\mathrm{H}_{2} \mathrm{O} \rightarrow \mathrm{H}_{2} \mathrm{O}^{*}\left(\text { Excitation of } \mathrm{O}_{2}\right. \text { molecule by UV) } \\
\mathrm{UV}+\mathrm{H}_{2} \mathrm{O}^{*} \rightarrow \mathrm{OH}^{-}+\mathrm{H}^{+}
\end{gathered}
$$




$$
\begin{aligned}
& \mathrm{e}^{-}+\mathrm{OH}^{-} \rightarrow \cdot \mathrm{OH}+\mathrm{e}^{-} \\
& \cdot \mathrm{OH}+{ }^{\bullet} \mathrm{OH} \rightarrow \mathrm{H}_{2} \mathrm{O}_{2} \text { (Recombination of }{ }^{\bullet} \mathrm{OH} \text { to form } \mathrm{H}_{2} \mathrm{O}_{2} \text { ) } \\
& \bullet \cdot \mathrm{OH}+\mathrm{H}_{2} \mathrm{O}_{2} \rightarrow \mathrm{HO}_{2}+\mathrm{H}_{2} \mathrm{O} \\
& \mathrm{H}_{2} \mathrm{O}_{2} \rightarrow \cdot \mathrm{OH}+{ }^{\bullet} \mathrm{OH}
\end{aligned}
$$

\subsection{Influencing Parameters in SPP under Aqueous Solutions}

In the SPP, the electrical discharges under a different type of aqueous solutions, and by using different electrode types, and repetition frequency have been investigated and reveals the influence on the electrical breakdown and the formation of reactive species [44]. The number density of ${ }^{\bullet} \mathrm{OH}$ was measured in a bipolar electrical discharge between tips of wire-type tungsten electrodes in aqueous solutions containing $\mathrm{HCl}, \mathrm{KCl}$, and $\mathrm{KOH}$ at the same conductivity $(500 \mu \mathrm{S} / \mathrm{cm})$ by Miron et al. [54]. The breakdown voltage occurred at $920 \mathrm{~V}$ for $\mathrm{HCl}, 850 \mathrm{~V}$ for $\mathrm{KCl}$, and $478 \mathrm{~V}$ for $\mathrm{KOH}$, which implied that the energy required for the plasma breakdown was higher for the $\mathrm{HCl}$ solution than for the solution $\mathrm{KCl}$ and $\mathrm{KOH}$. Additionally, the liquid conductivity measurement, which can suggest the ionization and dissociation of water to form hydrogen ions, was found to be relatively higher for the $\mathrm{HCl}$ solution. As the conductivity increased (up to approximately $520 \mu \mathrm{S} / \mathrm{cm}$ ), the discharge became stronger, accelerating the erosion of the metal surface, due to the process of secondary release. The secondary release results in increasing the possibility of the collision from ions to metal electrode surface in the electron-rich sheath near the tip of electrodes and increases the collision possibility of ions [55,56]. This erosion causes an increase in the distance between the tips of electrodes. The distance between the tips of electrodes in the $\mathrm{HCl}$ solution increased from $0.1 \mathrm{~mm}$ to $0.17 \mathrm{~mm}$, while $0.12 \mathrm{~mm}$ and 0.15 $\mathrm{mm}$ were observed in the $\mathrm{KCl}$ and $\mathrm{KOH}$ solution, respectively. Accordingly, it suggested that acidity has a significant influence on the sputtering of metal electrodes in the SPP, which is considered as an advantage for the synthesis of metal-based nanoparticles without using precursors and reducing agents [32,38,57]. Furthermore, the investigation on the formation of ${ }^{\bullet} \mathrm{OH}$ was also conducted via the time-resolved optical emission measurement at various time delays to the positive voltage pulse in the range of 0-38 $\mu$ s. The density of ${ }^{\bullet} \mathrm{OH}$ generated in $\mathrm{HCl}$ solution was found to be high $\left(2 \times 10^{17} \mathrm{~cm}^{-3}\right)$, while $\mathrm{KOH}$, which is highly basic and can be an important source of ${ }^{\bullet} \mathrm{OH}$, showed the lowest density $\left(5 \times 10^{16} \mathrm{~cm}^{-3}\right)$. This may be caused by the collision of $\mathrm{H}^{+}$, which may easily move in the opposite direction of electron flow owing to low atomic weight, on the surface of metal electrodes, compared to that of $\mathrm{K}^{+}$. The collisions result in the sputtering and the release of electrons or excited metal atoms, which can further react with water molecules and promote the generation of ${ }^{\bullet} \mathrm{OH}$ via the reactions showed above in Equation (4). In the nanosecond pulsed plasma discharge system for water-film plasma reactor, the influence of liquid conductivity on the electrical breakdown and the production of $\mathrm{H}_{2} \mathrm{O}_{2}$ was also studied by Wang et al. [58]. The breakdown voltage was found to be decreased with increasing liquid conductivity (from $100 \mu \mathrm{S} / \mathrm{cm}$ to $36,000 \mu \mathrm{S} / \mathrm{cm}$ ). This was explained by the decrease of dielectric relaxation time, which is the time scale of relaxation for moving charge carriers in materials. Increasing the liquid conductivity reduced the resistance of the liquid and facilitated the current to flow through the liquid when the electrical field was applied at the electrodes. This also caused the increment of energy dissipation into the bulk liquid. However, the production rate of $\mathrm{H}_{2} \mathrm{O}_{2}$, which can be a source for ${ }^{\bullet} \mathrm{OH}$, did not change significantly with conductivity. Moreover, the mixture of aqueous solution and organic solvent, like ethanol, was also investigated by Takeuchi et al. [59]. The breakdown was delayed, and the time needed until the steady-state discharge (constant current) was longer for the mixture with $50 \%$ ethanol, compared to the aqueous solution alone. This is because the ionization energy of an ethanol molecule $(16 \mathrm{eV})$ is higher than that of a water molecule $(13 \mathrm{eV})$. The total ionization cross-section of ethanol is larger than that of water with electron energy higher than $16 \mathrm{eV}[60,61]$, as shown in Figure 5. 


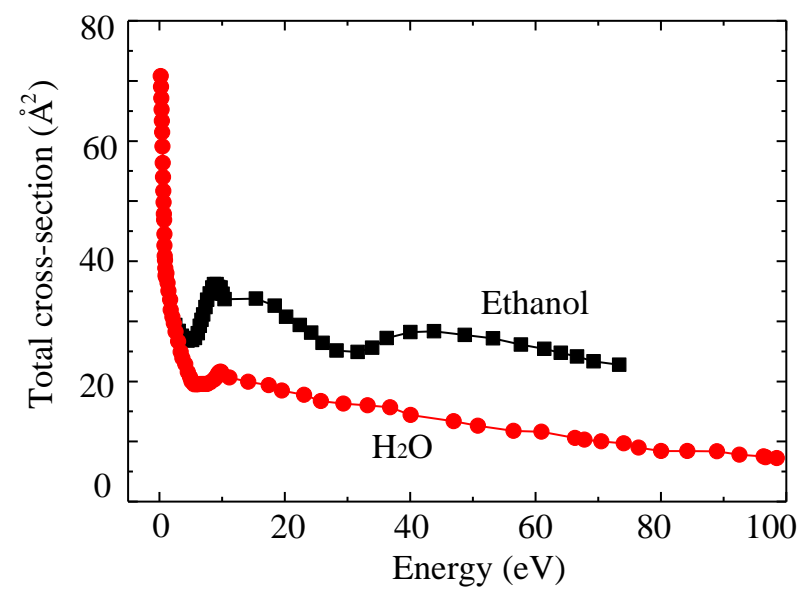

Figure 5. The total ionization cross-section of water and ethanol $[60,61]$.

However, the discharge probability increased with the addition of ethanol to the solution and the power required to produce bubbles and initiated a discharge that decreased with the addition of ethanol. This could be caused by the lower boiling temperature of ethanol, as compared to that of water. Furthermore, the discharge in the solution with ethanol (50\%) was found to produce smaller-size bubbles than that obtained in the solution without ethanol, which resulted in easier sustaining discharges and higher discharge probability higher. Besides, the OES spectra from solution without ethanol and with ethanol showed $\bullet^{\bullet} \mathrm{OH}, \bullet^{\bullet} \mathrm{H}$, and $\bullet^{\bullet} \mathrm{O}$, while the solution with ethanol showed relatively weak signals of ${ }^{\bullet} \mathrm{OH}$ and ${ }^{\bullet} \mathrm{O}$. However, the emissions of $\mathrm{C}_{2}$ swan band $(440 \mathrm{~nm})$ and ${ }^{\bullet} \mathrm{CH}$ $(431 \mathrm{~nm})$ could be observed in the solution with ethanol, due to the dissociation of ethanol vapor. This evidence shows benefit in the synthesis of carbon nanomaterials via the solution plasma process, similar to the systems with other organic solvents [27,62]. According to the evidence previously showed, it pointed out that the choice of solutions, which include conductivity, $\mathrm{pH}$, and type of ions, exhibits a significant effect on the properties of plasmas in liquids.

Types of electrodes also showed a significant effect on the electrical breakdown and generation of ${ }^{\bullet} \mathrm{OH}$ in the solution plasma process. In 2010, Miron et al. studied the currentvoltage characteristics and the optical emission spectroscopy in the solution plasma process by using tantalum $(\mathrm{Ta})$ and tungsten $(\mathrm{W})$ electrodes with the circulated and non-circulated water systems [63]. In comparison, the energy required for the electrical breakdown was also found to be higher for the systems with Ta electrodes. The current-voltage characteristics for all systems showed the features of a spark discharge, and the transition to arc plasma was observed in the case of using Ta electrodes. Furthermore, according to the OES spectra, the transition of the ${ }^{\bullet} \mathrm{OH}$ was found to be different for the circulated water and the non-circulated water discharges when different electrodes were used in the discharge. For $\mathrm{W}$ electrodes, the band of the ${ }^{\bullet} \mathrm{OH}$ was detected to be the strongest at 307.8 $\mathrm{nm}$, while the band was strongest at $312.6 \mathrm{~nm}$ for the Ta electrodes. The reason for this phenomenon was explained relating to the different plasma temperatures in the case of $W$ and Ta electrodes. Moreover, the board emission continuum spectra in the range spectra in the range of 350-940 nm were exhibited only for Ta electrodes, which might be due to the eroded and heated metal particles from the metal surface at the tips of electrodes. Later, in 2011, Miron et al. also studied the influence of electrodes made of $W$ and lanthanum hexaboride $\left(\mathrm{LaB}_{6}\right)$, on the electrical breakdown in water [64]. The polished asperities of electrodes showed different morphologies, which caused the difference of electric field required for the electrical breakdown $(\sim 190 \mathrm{kV} / \mathrm{cm}$ for $W$ electrodes and $\sim 160 \mathrm{kV} / \mathrm{cm}$ for $\mathrm{LaB}_{6}$ ). The rougher surface of $\mathrm{LaB}_{6}$ shown in Figure 6 had a higher number of locally concentrated emission sites than that of $\mathrm{W}$ electrodes. In addition, the melting points of these two materials $\left(3422{ }^{\circ} \mathrm{C}\right.$ and $2220^{\circ} \mathrm{C}$ for $\mathrm{W}$ and $\mathrm{LaB}_{6}$, respectively) were believed to be the factor for the erosion of electrodes, which resulted in the formation of different reactive 
species under corresponding plasma condition. Even though the erosion of metal electrodes could cause contamination to final products in the modification process by the SPP, this phenomenon has also given benefits to the synthesis of metal nanoparticles without using precursors and reducing agents [32]. The influence of electrode types on the generation of reactive species has been continuously investigated. Goto et al. also investigated the electrical discharge in water by using copper $(\mathrm{Cu})$ electrodes. They found the emission line of atomic $\mathrm{Cu}$ in the optical emission spectra and proposed that the $\mathrm{Cu}$ atoms may act as a catalyst to promote the generation of ${ }^{\bullet} \mathrm{OH}$ [51]. Besides, not only the influence of electrode types but also the polishing of electrodes is also an essential step for the SPP. Yui et al. reported that the sharpening could increase the stability of the spatial position of the plasma [5]. Accordingly, the management of electrode tips, such as polishing surface and sharpening, should be done, depending on the application. Sharpening electrodes that can provide the high stability of plasma may be suitably applied in precisely controlled chemical reactions. Meanwhile, reactions like degradation require a large plasma with high production of reactive species, which polishing surface of electrode tips suffices.
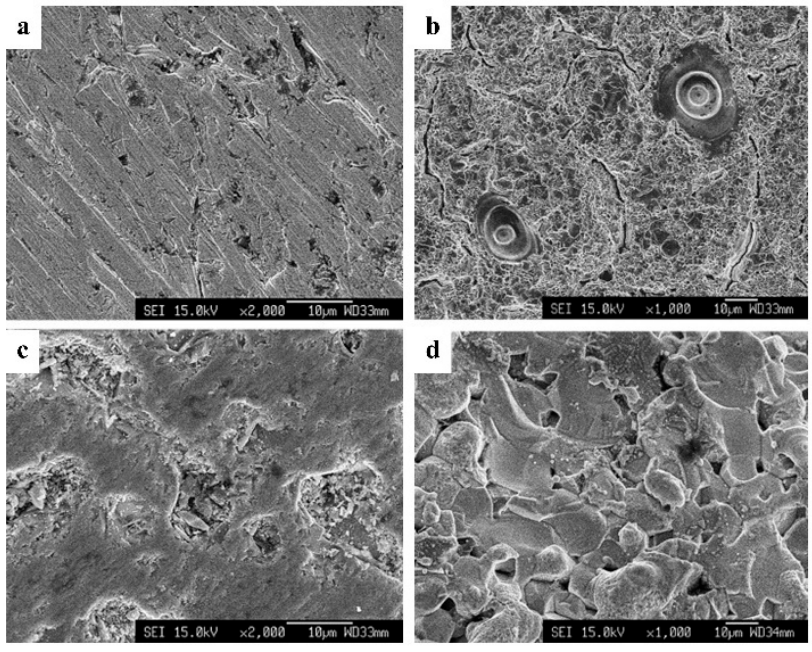

Figure 6. SEM images of the surface of the $W$ electrodes (a) before and (b) after being exposed to $10 \mathrm{~min}$ of the discharge and SEM images of the surface of the $\mathrm{LaB}_{6}$ electrodes (c) before and (d) after being exposed to $10 \mathrm{~min}$ of the discharge [64].

The plasma parameters, such as frequency, were found to be related to the relative amount of injected energy per pulse [20]. Unfortunately, the investigation was conducted by applying the pulse frequency using the bipolar power supply (from 25 to $65 \mathrm{kHz}$ ) in only benzene, which led to the formation of carbon materials. The result showed that there were two different operation regimes. The first regime, characterized as glow discharge, occurred when the pulse frequency ranged between 25 and $50 \mathrm{kHz}$ was applied, which referred to lower energy input at a certain interval. In comparison, the second regime, characterized as spark discharge, could be obtained by applying the pulse frequency of $65 \mathrm{kHz}$, which could result in relatively high energy input in the corresponding period. The plasma/gas temperature was reported to be increased with increasing energy input, which might influence the obtained carbon products from each regime to reveal different morphology. Therefore, it is possible that the electrical discharge in aqueous solutions can also be influenced by applying different frequencies.

Many researchers also attempted to enhance the efficiency of electrical discharge under aqueous solutions by adding bubbles into the system with different configurations, as revealed in Figure 7a,b. The configuration in Figure 7a was proposed by Goto et al. They studied the formation of hydrogen peroxide, which is a powerful oxidant, by applying bipolar pulsed voltage with fine $\mathrm{O}_{2}$ bubbles [51]. The result showed that the high concentration of dissolved $\mathrm{O}_{2}$ insignificantly increases the amount of $\mathrm{H}_{2} \mathrm{O}_{2}$. Moreover, Yui et al. developed a direct gas injection system at the tip of the electrode, as shown 
in Figure $7 \mathrm{~b}[5,65]$. The injecting gases were $\mathrm{O}_{2}, \mathrm{CO}_{2}, \mathrm{~N}_{2}$, and Ar. The injection of gases caused the spatial fluctuation of plasma. The electron number density in the plasma was found to be increased by injecting $\mathrm{O}_{2}, \mathrm{CO}_{2}$, and $\mathrm{N}_{2}$. It was because the generation of electrons in the plasma was increased by the enhanced collision between the positively charged ions, which can be accelerated by the applied voltage, and other particles, ions, and the cathodic electrode. The kinetic impulses of the collision increased due to the injected gases with larger molecular weights than $\mathrm{H}_{2} \mathrm{O}$. On the other hand, the injection of Ar gas resulted in the reduction of electron number density. This is because Ar is an inert gas that has a larger ionization energy of $1500 \mathrm{~kJ} / \mathrm{mol}$, as compared to other gases, such as $\mathrm{O}_{2}(1175 \mathrm{~kJ} / \mathrm{mol})$. The contents of the plasma, characterized by the OES, were found to be different, as illustrated in Figure 8.

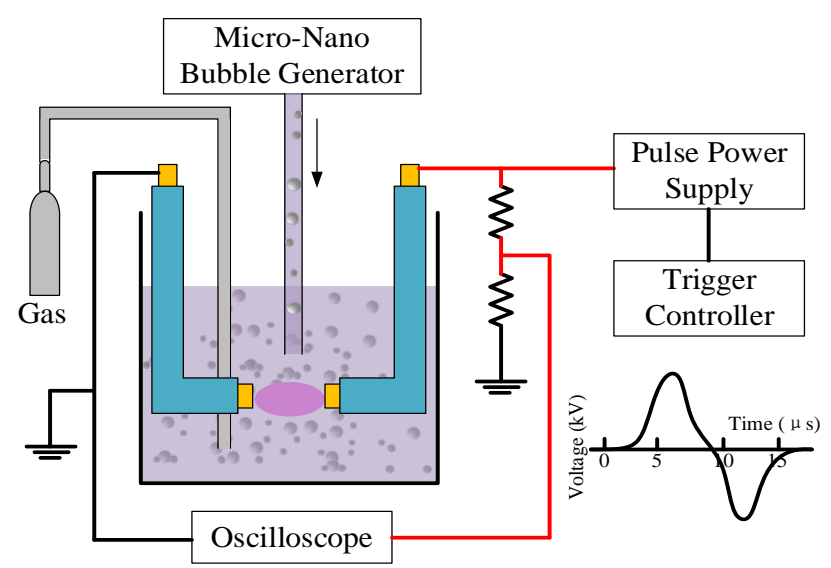

(a)

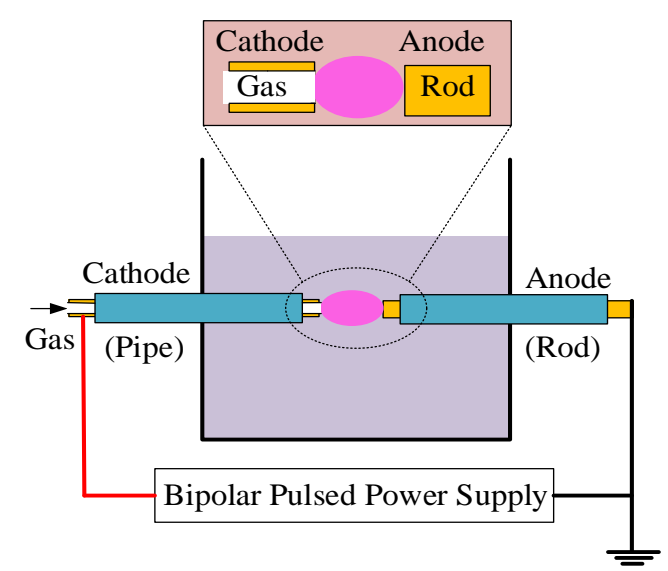

(b)

Figure 7. Systems with different configurations of adding bubbles, proposed by (a) Goto et al. [51] and (b) Yui et al. [65].

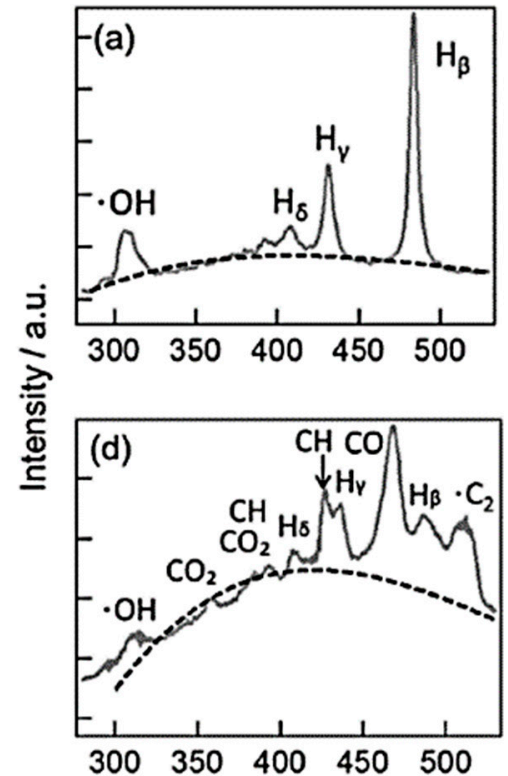

$\begin{array}{lllll}300 & 350 & 400 & 450 & 500\end{array}$
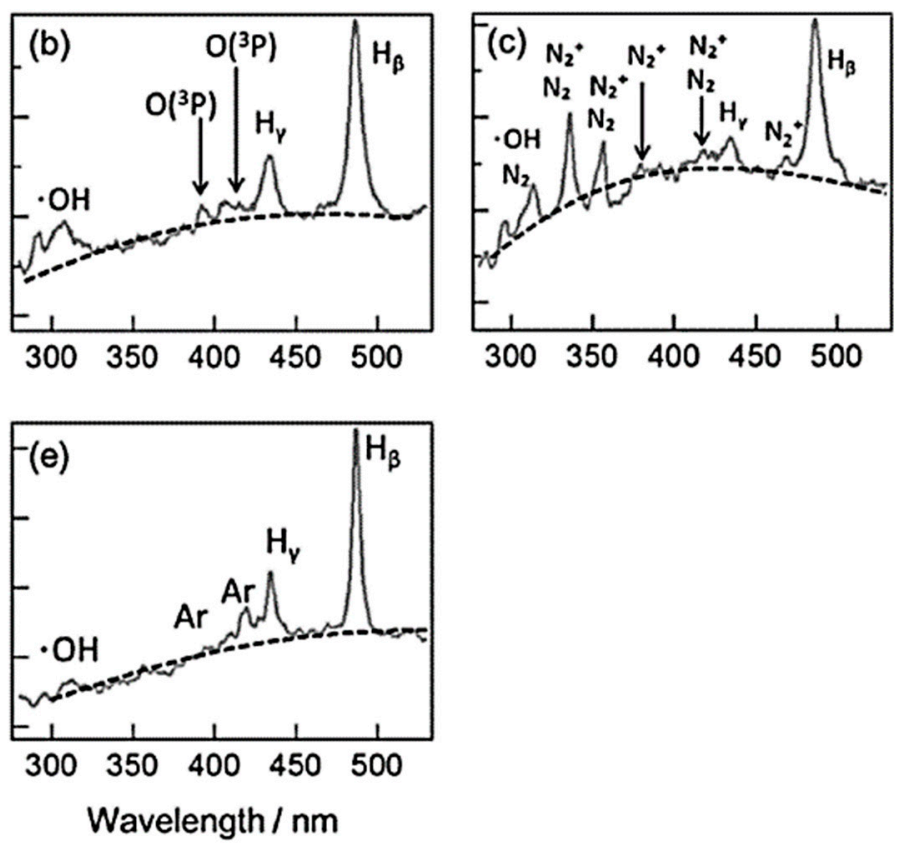

Figure 8. OES spectra from the solution plasma process without the gas injection (a), and with the injections of $\mathrm{O}_{2}(\mathbf{b})$, $\mathrm{N}_{2}$ (c), $\mathrm{CO}_{2}(\mathbf{d})$, and $\mathrm{Ar}(\mathbf{e})$. The spectra were obtained with an integration time of $12.8 \mathrm{~s}$, and 320,000 pulses were integrated during the time span. The black dotted lines represent the best-fitted curves with the blackbody radiation [65]. 


\section{Solution Plasma Process for Modification of Chitin and Chitosan}

\subsection{Chitin and Chitosan}

Chitin was first discovered in the early nineteenth century. It can be extracted from crustacean shell waste (e.g., shrimp and crab shells), insects, and plants [66,67]. Similar to cellulose, it functions as a structural linear polysaccharide. Unlike cellulose, it contains acetamido and amino groups at C-2 position on its pyranose rings [68]. Figure 9 shows the chemical structure of chitin consisting of 2 -acetamido-2-deoxy- $\beta$-D-glucopyranose as a major repeating unit and glucosamine connected by $\beta(1 \rightarrow 4)$ linkages. Chitosan is one of the most studied chitin derivatives, which is obtained by deacetylation of chitin [69]. Due to the deacetylation reaction, acetyl groups are removed and converted to amino groups, as revealed in Figure 9. The presence of amino groups in the chitosan structure is responsible for its unique functional and biological properties, depending on its molecular weight, as revealed in Figure 10 [70-72]. Moreover, chitin and chitosan also have interesting characteristics, such as biocompatibility, non-toxicity, low allergenicity, and biodegradability. However, their original chemical structures (e.g., high molecular weight and strong hydrogen-band network) cause poor solubility in organic solvents and water, which limit utilization in several fields, especially in biomedical applications [73]. To improve their properties and broaden their applications, chitin and chitosan are intensively studied and modified. For example, degradation of chitin and chitosan to obtain water-soluble degraded products (e.g., chitooligosaccharides), and chemical modification of its functional groups (e.g., deacetylation, carboxymethylation).
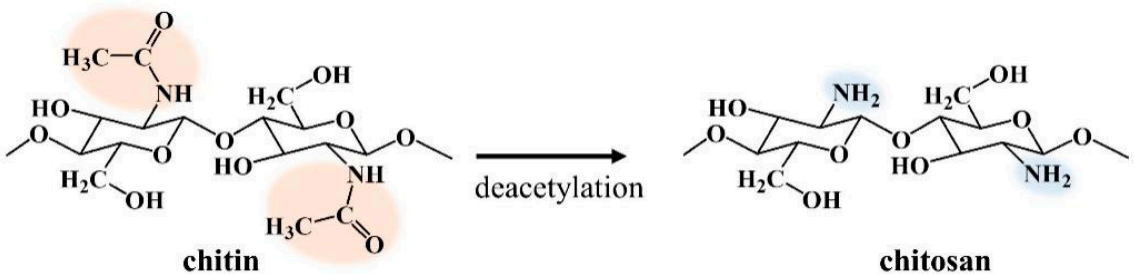

chitosan

Figure 9. Chemical structures of chitin and chitosan.

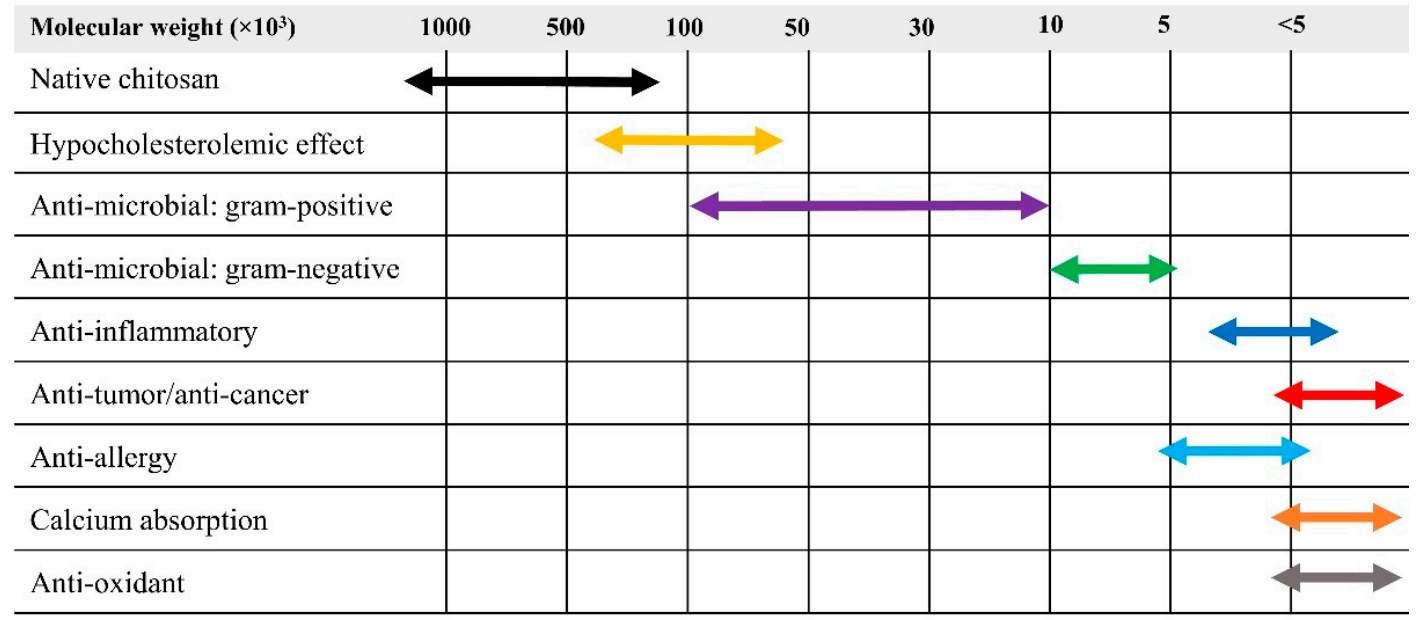

Figure 10. Biological properties of chitosan, depending on its molecular weight. (Note: native chitosan $[39,41,67,74]$, hypocholesterolemic effect [75], anti-microbial: gram-positive [76], anti-microbial: gram-negative [76], anti-inflammatory [77], anti-tumor/anti-cancer [39,49,74,78], anti-allergy [79], calcium absorption [80], anti-oxidant [81]).

Several protocols can be used to modify chitin and chitosan. In general, they can be categorized into three main methods: (i) chemical method [82,83], (ii) enzymatic method [84,85], and (iii) physical method [86-88]. Chemical methods typically give high efficiency or high rate in the modification of chitin and chitosan. However, their drawbacks are concerned with the cost of chemicals, waste management, and severe reactions, 
resulting in unwanted products (e.g., some over-degraded products). Enzymatic methods can provide a mild reaction and selectively modify chitin and chitosan [89]; for example, it can produce specific oligomers of chitin and chitosan, as shown in Table 1. However, the process is time-consuming, and the cost of handling is relatively high. In recent years, exploring alternative techniques for chitin and chitosan modification, physical methods for the modification of chitin and chitosan, have focused on the utilization of various kinds of energy, including irradiation [90], sonication [91], microwave [92], and plasma. These methods can provide rapid reactions with relatively lower chemical uses and low contamination in the final product, compared to enzymatic and chemical methods, respectively. Among these methods, liquid-phase plasma treatment of chitosan in aqueous solutions is believed to be a novel and effective method, examples of which are given in Tables 1 and 2 (in case of degradation of chitosan). Therefore, it should be clearly understood, aiming at further development.

Table 1. Degradation of chitin and chitosan via chemical and enzymatic methods.

\begin{tabular}{|c|c|c|c|c|c|}
\hline Chemicals & $\begin{array}{c}\text { Chemical } \\
\text { Concentration }\end{array}$ & Temperature & Time & $\begin{array}{c}\text { MW/ } \\
\text { Products }\end{array}$ & Ref. \\
\hline Hydrochloric acid & $35 \%$ & $80{ }^{\circ} \mathrm{C}$ & $1.4 \mathrm{~h}$ & $3-5 \times 10^{3}$ & [93] \\
\hline Hydrochloric acid & $12 \mathrm{M}$ & $40{ }^{\circ} \mathrm{C}$ & $8 \mathrm{~h}$ & $1-3 \times 10^{3}$ & [94] \\
\hline Nitrous acid & $70 \mathrm{mM}$ & $0^{\circ} \mathrm{C}$ & $9 \mathrm{~h}$ & $2-6 \times 10^{3}$ & [95] \\
\hline Hydrogen fluoride & $100 \%$ & $20{ }^{\circ} \mathrm{C}$ & $19 \mathrm{~h}$ & $\sim 2 \times 10^{3}$ & [96] \\
\hline Hydrogen peroxide & $30 \%$ & $70{ }^{\circ} \mathrm{C}$ & $2 \mathrm{~h}$ & $1.7-3.81 \times 10^{3}$ & [97] \\
\hline $\begin{array}{l}\text { Chitosanase } \\
\text { (Bacillus pumilus BN-262) }\end{array}$ & $0.1 \mathrm{M} \mathrm{NaOAc} \mathrm{buffer,} \mathrm{pH} 5.3$ & $37^{\circ} \mathrm{C}$ & $96 \mathrm{~h}$ & $2-3$ oligomers & [98] \\
\hline $\begin{array}{c}\text { Chitinase } \\
\text { (Vibrio furnissii) }\end{array}$ & Chitin in DMSO/LiCl, pH 7.9 & $37^{\circ} \mathrm{C}$ & $24 \mathrm{~h}$ & 2 oligomers & [99] \\
\hline Papain & NaOAc-AcOH buffer, pH 4.0 & $45^{\circ} \mathrm{C}$ & $24 \mathrm{~h}$ & 2-50 oligomers & [100] \\
\hline
\end{tabular}

Table 2. Degradation of chitin and chitosan via physical methods.

\begin{tabular}{|c|c|c|c|c|c|}
\hline Methods & $\begin{array}{c}\text { Chemical } \\
\text { Concentration }\end{array}$ & $\mathrm{T}\left({ }^{\circ} \mathrm{C}\right)$ & Time & $\begin{array}{c}\% \text { MW } \\
\text { Reduction }\end{array}$ & Ref. \\
\hline $\begin{array}{c}\text { Microwave } \\
400 \mathrm{~W}\end{array}$ & $2 \%$ acetic acid & $\mathrm{N} / \mathrm{A}$ & $25 \min$ & $79 \%$ & [101] \\
\hline $\begin{array}{l}\text { Microwave } \\
100 \mathrm{~W}\end{array}$ & $0.1 \mathrm{M}$ acetic acid & $\mathrm{N} / \mathrm{A}$ & $20 \mathrm{~min}$ & $92.5 \%$ & [87] \\
\hline $\begin{array}{l}\text { Ultraviolet } \\
1 \mathrm{~kW} \text { power }\end{array}$ & $0.1 \mathrm{M}$ acetic acid & 25 & $15 \mathrm{~min}$ & $98.5 \%$ & [88] \\
\hline $\begin{array}{l}\text { Ultrasonication } \\
200 \mathrm{~W}\end{array}$ & $0.1 \mathrm{M}$ acetic acid & $\mathrm{N} / \mathrm{A}$ & $120 \mathrm{~min}$ & $52 \%$ & [88] \\
\hline $\begin{array}{l}{ }^{60} \mathrm{Co} \gamma \text {-rays } \\
\text { Radiation }\end{array}$ & $\begin{array}{l}2 \% \text { acetic acid mixed } 10 \mathrm{~mL} \text { hydrogen } \\
\text { peroxide }\end{array}$ & $\mathrm{N} / \mathrm{A}$ & $7 \mathrm{~h}$ & $95 \%$ & [102] \\
\hline $\begin{array}{l}\text { Impinging stream and } \\
\text { jet cavitation }\end{array}$ & $\begin{array}{c}\text { acetic acid mixed with sodium acetate } \\
\text { trihydrate }\end{array}$ & 40 & $30 \mathrm{~min}$ & $88 \%$ & [103] \\
\hline $\begin{array}{l}\text { Hydrodynamic } \\
\text { cavitation }\end{array}$ & $\begin{array}{l}0.2 \text { acetic acid mixed with } 0.1 \text { sodium } \\
\text { acetate }\end{array}$ & 40 & $30 \mathrm{~min}$ & $95 \%$ & [104] \\
\hline $\begin{array}{l}\text { Plasma } \\
350 \mathrm{~W}\end{array}$ & $1 \%$ acetic acid & $\mathrm{N} / \mathrm{A}$ & $180 \mathrm{~min}$ & $83 \%$ & [105] \\
\hline SPP & $1 \mathrm{M}$ acetic acid & $25-30$ & $300 \mathrm{~min}$ & $\mathrm{n} / \mathrm{a}$ & [46] \\
\hline SPP & $1 \mathrm{M}$ acetic acid & $25-30$ & $300 \mathrm{~min}$ & $96 \%$ & [40] \\
\hline SPP & $\begin{array}{c}0.1 \mathrm{M} \text { acetic acid } \\
4 \mathrm{M} \text { hydrogen peroxide }\end{array}$ & Room temperature & $60 \mathrm{~min}$ & $85 \%$ & [74] \\
\hline SPP & $0.00155 \mathrm{mM}$ carboxylic acids & Room temperature & $60 \mathrm{~min}$ & $86 \%$ & [106] \\
\hline SPP & $0.02 \mathrm{M}$ sodium chloride & Room temperature & $60 \mathrm{~min}$ & $96 \%$ & [39] \\
\hline
\end{tabular}




\subsection{Reduction of Molecular Weight and Destruction of Crystallinity Via SPP}

There are several SPP parameters that have been investigated to understand the degradation process to reduce the molecular weight of chitosan, such as reaction time, electrode configuration, types of electrodes, and frequency. In 2012, the SPP was introduced for the first time to reduce the molecular weight of chitosan by Prasertsung et al. [46]. Chitosan is insoluble in water and organic solvents, but it is soluble in dilute aqueous acidic solution at $\mathrm{pH}<6.5$. The dissolution resulted in the protonation of the amino group $\left(\mathrm{R}-\mathrm{NH}_{2}\right)$ in glucosamine units into soluble form $\mathrm{R}-\mathrm{NH}_{3}{ }^{+}$. To obtain a homogeneous reaction solution, chitosan was dissolved in acetic acid prior to the SPP. The molecular weight of chitosan sharply dropped in the beginning (0-60 $\mathrm{min})$ and then gradually decreased, approaching a constant. Reactive species, like ${ }^{\bullet} \mathrm{OH}$, was believed to play an important role in the molecular weight reduction of chitosan. As a result, the longer time of the reaction had a lesser effect on the reduction of molecular weight because the number of short-chain chitosan increased while the number of ${ }^{\bullet} \mathrm{OH}$ produced in the system remained the same according to the fixed SPP condition. Moreover, they also reported that the main structure (pyranose ring) was not altered after the solution plasma process. Besides, Prasertsung et al. also applied the SPP on the molecular weight reduction of $\beta$-chitosan [40]. $\beta$-chitosan has a low hydrogen-bonding network, leading to loss in crystalline structure, compared to normal chitosan, which mostly refers to $\beta$-chitosan. Compared to their previous study using $\alpha$-chitosan, the reaction rate was higher. The molecular weight of $\beta$-chitosan $\left(5.5 \times 10^{5}\right)$ was markedly decreased from almost 4 times $\left(1.5 \times 10^{5}\right)$ and 30 times $\left(1.9 \times 10^{4}\right)$ after the solution plasma treatment for $30 \mathrm{~min}$ and $300 \mathrm{~min}$, respectively. The water solubility of the obtained products was also found to be improved. Accordingly, the tuning of the SPP treatment time showed potential to obtain chitosan with specific molecular weight, which can be further used in various applications, as shown in Figure 10.

In addition, the effect of SPP on the chitosan derivatives, N,O-carboxymethyl chitosan decorated with gold nanoparticles, water-soluble chitosan with a highly negative charge, was also studied by Chokradjaroen et al. [49]. In their study, chemical reduction of $\mathrm{Au}^{3+}$ was firstly conducted in N,O-carboxymethyl chitosan solution, as shown in Figure 11. The aggregation of gold nanoparticles could be observed. However, after the SPP, the distribution of gold nanoparticles was improved and their average size was also reduced from $11 \mathrm{~nm}$ to $9 \mathrm{~nm}$, as shown in TEM images (Figure 12). A similar result was also reported and explained that as the SPP prolonged, the $\mathrm{pH}$ of the solution decreased, leading to the partial dissolution of metal nanoparticles [28]. Not only the change in the size of gold nanoparticles but also the hydrodynamic size, which referred to the molecular weight of $\mathrm{N}$,O-carboxymethyl chitosan, was also influenced by the ${ }^{\bullet} \mathrm{OH}$ formed in the system. The chain scission of $\mathrm{N}, \mathrm{O}$-carboxymethyl chitosan was occurred by the attacking of $\bullet \mathrm{OH}$ to $\mathrm{C}-1$ position of chitosan, resulting in the bond breakage at $\beta$-glycosidic linkages, as shown in Figure 11. After the reaction, the result of chemical structure analysis showed that there was no destruction of the main structure and functional groups, including carboxymethyl group and interaction with gold nanoparticles. Nevertheless, the negative charge of N,O-carboxymethyl chitosan decorated with gold nanoparticles was lowered in magnitude, according to the Zeta potential measurement. Consequently, the obtained products were evaluated and showed enhanced cytotoxicity and improved the selectivity toward cancer cells than normal cells.

In addition to the effect of reaction time, the effects of SPP conditions (e.g., electrode types and pulse frequency) also play an important role in the degradation rate and properties of chitosan. Prasertsung et al. used various types of electrodes, including tungsten $(\mathrm{W})$, copper $(\mathrm{Cu})$, and iron $(\mathrm{Fe})$, and varied the applied pulse frequency of the bipolar supply from 15 to $30 \mathrm{kHz}$ [47]. According to the obtained result, the different electrode types differently affected the degradation of chitosan. Within $60 \mathrm{~min}$, the molecular weight of chitosan could be reduced from $1.3 \times 10^{5}$ to $8.7 \times 10^{4}, 6.2 \times 10^{4}$, and $4.1 \times 10^{4}$ for the system with $\mathrm{W}, \mathrm{Cu}$, and $\mathrm{Fe}$ at $15 \mathrm{kHz}$, respectively. The melting points of $\mathrm{W}, \mathrm{Cu}$, and $\mathrm{Fe}$ are $3422{ }^{\circ} \mathrm{C}, 1084{ }^{\circ} \mathrm{C}$, and $1204^{\circ} \mathrm{C}$. A stronger promoting effect of the system with $\mathrm{Cu}$ and 
Fe electrodes could be attributed to the metal atoms or ions from the erosion of the metal surface at the tip of electrodes during plasma treatment. Especially, metal atoms and ions from iron electrodes could be transformed into ferrous ions and effectively participate in the Fenton reaction. The decomposition of $\mathrm{H}_{2} \mathrm{O}_{2}$ generated in the system led to the increment of ${ }^{\bullet} \mathrm{OH}$. Besides, the pulse frequency was found to significantly influence the reduction of the molecular weight of chitosan. After the solution plasma process at the applied pulse frequencies of $15,22.5$, and $30 \mathrm{kHz}$, the molecular weights of the obtained products were $1.3 \times 10^{4}, 9.2 \times 10^{3}$, and $6.8 \times 10^{3}$, respectively. This could be described by the raising of the energy input when the pulse frequency increased. However, the molecular weight distributions of the obtained products were still relatively high, which is not suitable for many applications. The polydispersity index (PDI) ranged from 2.5 to 3.5 , which was higher than the ideal PDI (1). In biomedical applications, monodisperse low molecular weight chitosan or chitooligosaccharides, $\mathrm{COS},(\mathrm{PDI}=1)$ is desired.

To acquire the specific product of low-molecular-weight chitosan with high purification, several techniques were studied in combination with the SPP. For example, Pornsunthornthawee et al. used the benefit of the chitosan-metal complex to induce the selective chain scission. Metal ions, such as silver ion $\left(\mathrm{Ag}^{+}\right)$, zinc ion $\left(\mathrm{Zn}^{2+}\right)$, copper (II) ion $\left(\mathrm{Cu}^{2+}\right)$, and ferric ion $\left(\mathrm{Fe}^{3+}\right)$, were used to form complexes with chitosan, which was dissolved in the acid solution, at a metal-to-chitosan molar ratio of 1:8 [41]. The hydroxyl groups (-OH) and amine $\left(-\mathrm{NH}_{2}\right)$ groups in the chitosan structure can act as good ligands for coordination with the metal ions. This coordination usually causes the weakening of covalent bonds near the coordinating site, leading to weak points which can promote the chain-scission reaction, as shown in Figure 13. As a result, the complexation of chitosan with $\mathrm{Cu}^{2+}$ or $\mathrm{Fe}^{3+}$ ions strongly promoted the degradation rate of chitosan, while chitosan- $\mathrm{Ag}^{+}$and chitosan- $\mathrm{Zn}^{2+}$ complexes exhibited slight change, compared to chitosan alone. After the SPP treatment for $180 \mathrm{~min}$, the only complexation with either $\mathrm{Cu}^{2+}$ could produce glucosamine and COS with a molecular weight of $10^{3}$ and PDI of 1.4. However, the reaction time was quite long, and the separation of the metal ions from the glucosamine and COS was required, prior to further use.

Later, the SPP was also combined with an environmental-friendly oxidizing agent (i.e., $\mathrm{H}_{2} \mathrm{O}_{2}$ ) and $\mathrm{O}_{2}$ bubbling in order to enhance the rate of reaction and lower the possibility of contamination to the final products, as well as move toward a greener process. Chokradjaroen et. al. found that the combination of SPP and $4 \mathrm{mM} \mathrm{H}_{2} \mathrm{O}_{2}$ could effectively promote the chain scission of chitosan, resulting in the significant decrease of molecular weight (from $450 \times 10^{3}$ to $50 \times 10^{3}$ ) within $60 \mathrm{~min}$ [74]. The degradation mechanism of chitosan by applying the SPP in combination with $\mathrm{H}_{2} \mathrm{O}_{2}$ was also proposed in this work. They explained that excitation and ionization of $\mathrm{H}_{2} \mathrm{O}$ molecules should mainly occur during the plasma discharge since the major component in the system was $\mathrm{H}_{2} \mathrm{O}$ molecules. Electrons emitted from ionization continuously collided with the surrounding $\mathrm{H}_{2} \mathrm{O}$ molecules to produce ${ }^{\bullet} \mathrm{OH}$. The addition of $\mathrm{H}_{2} \mathrm{O}_{2}$ could promote the reaction because $\mathrm{H}_{2} \mathrm{O}_{2}$ itself can dissociate to form ${ }^{\bullet} \mathrm{OH}$. This phenomenon helps to increase the ${ }^{\bullet} \mathrm{OH}$ concentration in the system and enhance the degradation of chitosan. Due to the relatively short reaction time and not too severe reaction, the prevention of over-degradation could be done. The obtained COS has an average molecular weight of $1.44 \times 10^{3}$ (8 oligomers), which has been reported to be suitable for anticancer activity. Moreover, Ma et al. reported on the effect of bubbling gas added in the solution plasma process on the molecular weight and physicochemical properties of chitosan [107]. They found that when the bubbling gas (i.e., $\mathrm{O}_{2}$ ) was presented in the SPP system, the concentration of ${ }^{\bullet} \mathrm{OH}$ increased, which caused not only the enhancement of molecular weight reduction but also influence on physical properties (e.g., destruction of crystallinity). Moreover, the SPP combined with $\mathrm{H}_{2} \mathrm{O}_{2}$ and $\mathrm{O}_{2}$ did not show a significant change on the pyranose ring and functional groups $(-\mathrm{OH}$, $-\mathrm{NH}_{2}$, etc.) of chitosan, which is a key possessing the biological properties. 


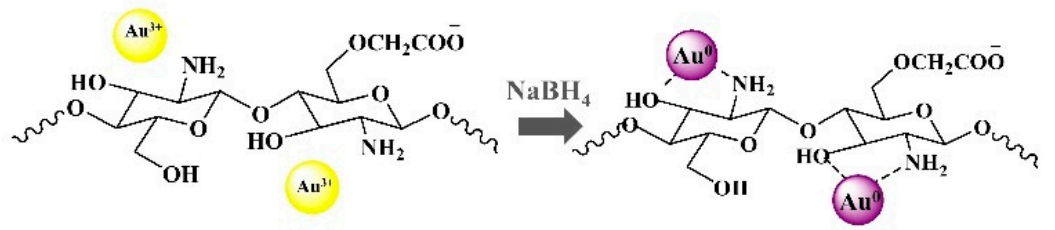

\section{Solution plasma process}

$\mathrm{H}_{2} \mathrm{O} \rightarrow \cdot \cdot \mathrm{OH}+\cdot \mathbf{H}$

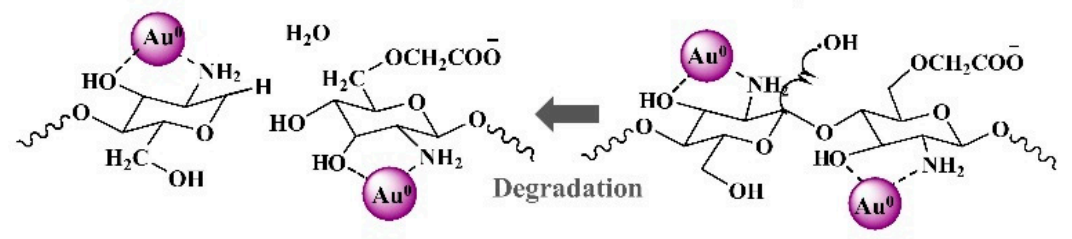

Figure 11. Illustration of a formation of N,O-carboxmethyl chitosan decorated with gold nanoparticles and a possible degradation mechanism by hydroxyl radicals generated by the SPP [49].

$\mathbf{a}$

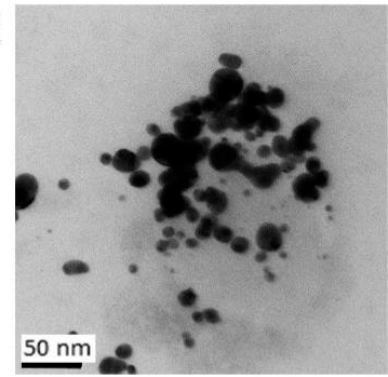

b

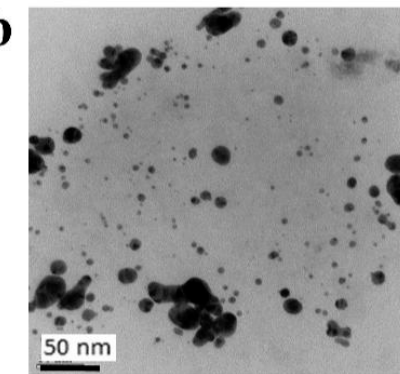

c

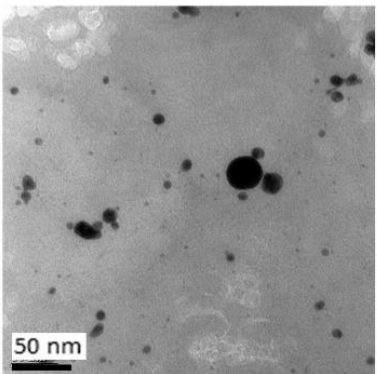

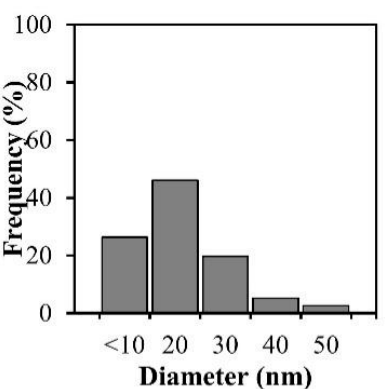

Diameter (nm)
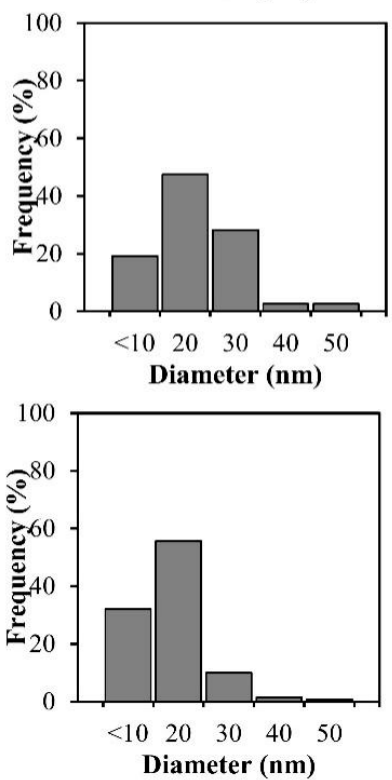

Figure 12. TEM images of the N,O-carboxmethyl chitosan decorated with gold nanoparticles (a) and the degraded products after degradation by the SPP for 45 (b) and $90 \mathrm{~min}$ (c) [49].

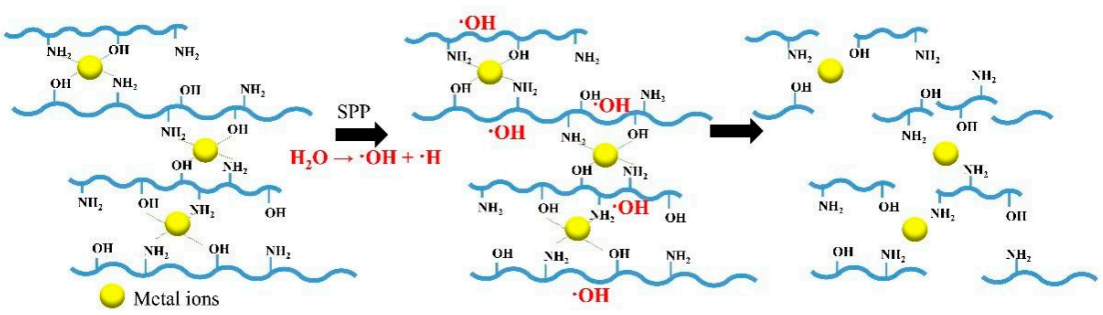

Figure 13. Degradation of chitosan-metal complexes via SPP. 
Several methods (e.g., microwave, sonication, and irradiation) have been claimed as green degradation of chitosan. However, in these methods as well as most studies using the SPP, chitosan is mostly dissolved in an acetic acid solution (approximately 1-2 M), to obtain a homogeneous chitosan solution prior to the degradation, as shown in Table 2. After the degradation, separating water-soluble COS from the high-molecular-weight chitosan is usually found to be complicated because they are dissolved together in the solution. Chokradjaroen et al. realized this issue; therefore, they had tried to propose a technique that can effectively produce chitosan with specific molecular weight, reduce the chemical use in the system, and simplify the post-treatment step, including the separation and purification processes. Accordingly, the heterogeneous degradation of chitosan by the SPP was proposed. For example, the heterogeneous degradation of chitosan hydrogel, which could hold a large amount of water in its three-dimensional networks, was conducted by the SPP with the presence of carboxylic acids (i.e., monocarboxylic acid, dicarboxylic acid, and tricarboxylic acid) at an acid-to-chitosan mole ratio of 1-to-8 ( 1.55 mM) [106]. The chitosan hydrogel with addition of carboxylic acids was found to have good mobility in the SPP reactor. According to the molecular weight of the obtained products, the number of carboxylic groups in the carboxylic acid exhibited the effect on the rate of reaction, molecular weight, and PDI of the obtained COS. Acetate anions $\left(\mathrm{CH}_{3} \mathrm{COO}^{-}\right)$ are small, which should be able to penetrate the three-dimensional networks of chitosan hydrogel and undergo ionic interaction with the protonated amino group $\left(-\mathrm{NH}_{3}{ }^{+}\right)$, leading to electrostatic repulsion and expansion between chitosan chains. The expansion was believed to facilitate the accessibility of ${ }^{\bullet} \mathrm{OH}$ to $\mathrm{C}-1$ position of chitosan. Besides, all dicarboxylic acids and tricarboxylic acid can dissociate in the water, based on their pKa. Therefore, ionic interactions between the $-\mathrm{NH}_{3}{ }^{+}$groups of chitosan and the $-\mathrm{COO}^{-}$groups of the carboxylic acids can occur. This can lead to ionic crosslinking or complexation of dicarboxylic and tricarboxylic acids with $-\mathrm{NH}_{3}{ }^{+}$groups of some adjacent chitosan chains, which should result in the weakening of the covalent bonds near the complexed sites. The COS obtained from the system with dicarboxylic acid had a similar molecular weight of approximately 2100 (PDI $=1.8$ ), while the tricarboxylic acid system could produce COS with $1500(\mathrm{PDI}=1.5)$. As a result, the complexation of dicarboxylic and tricarboxylic acids showed potential for the selective degradation of chitosan. Moreover, due to the use of carboxylic acids with an incredibly low concentration in the reaction, further purification after the centrifugation was unnecessary. The overall process became much simpler, compared to that of the homogenous chitosan solution, like in other studies. In addition, carboxylic acids were reported to be safe for use in food and drug production [108].

Furthermore, the fine power of chitosan was used and provided a good dispersion in the SPP reactor and led to the simpler degradation process of chitosan, compared to other previous techniques, as shown in Figure 14 [39]. A variety of sodium salts (e.g., $\mathrm{NaCl}, \mathrm{NaI}, \mathrm{NaNO}_{3}$, and $\mathrm{Na}_{2} \mathrm{SO}_{4}$ ) and metal chloride (e.g., $\mathrm{CaCl}_{2}, \mathrm{MnCl}_{2}$, and $\mathrm{CeCl}_{3}$ ) used in this work exhibited the different influence on the rate of degradation on the main structure (i.e., pyranose rings and functional groups) of chitosan. According to the result, the inorganic salts, such as $\mathrm{Na}_{2} \mathrm{SO}_{4}, \mathrm{NaCl}$, and $\mathrm{NaNO}_{3}$, could promote stable plasma formation as well as the molecular weight reduction of chitosan. After the plasma discharge, water-soluble and water-insoluble products can be easily observed, as revealed in Figure 15a. The morphology and crystallinity of the plasma-treated chitosan were also observed as a function of time (Figure 15b). The result showed evidence that both the degradation and destruction of crystallinity occurred simultaneously, as proposed in Figure 15c. For the presence of $\mathrm{NaI}, \mathrm{MnCl}_{2}$, and $\mathrm{CeCl}_{3}$ in the reaction solutions, they could not provide the effective molecular weight reduction of chitosan powder. In general, $\mathrm{NaI}$ can be dissociated to iodide ion $\left(\mathrm{I}^{-}\right)$, which can be oxidized to form iodine molecules. Meanwhile, $\mathrm{MnCl}_{2}$ and $\mathrm{CeCl}_{3}$ are a transition metal and a lanthanide, respectively, which have several oxidation states. Therefore, they can undergo some redox reactions. These reactions could probably compete with the degradation reaction, leading to the lowering of the degradation efficiency. The obtained COS products in their works were analyzed 
and evaluated for their cytotoxicity and showed that they were highly purified and had potential as a nature-derived anticancer agent.

Recently, the role of reactive species generated in the SPP system was intensively investigated by Ma et al. by using a technique based on radical scavenging (radical ${ }^{\bullet} \mathrm{OH}$ scavenger, tert-butanol; $\mathrm{H}_{2} \mathrm{O}_{2}$ scavenger, $\mathrm{MnO}_{2}$; radical ${ }^{\bullet} \mathrm{O}$ scavenger, 1,4-benzoquinone; hydrated electrons scavenger, $\mathrm{NaH}_{2} \mathrm{PO}_{4}$ ) [109]. The result showed that not only ${ }^{\bullet} \mathrm{OH}$ but also ${ }^{\circ} \mathrm{O}$ and $\mathrm{H}_{2} \mathrm{O}_{2}$ participate in the degradation of chitosan, while the hydrated electron played a partial role. The addition of ${ }^{\bullet} \mathrm{O}$ and $\mathrm{H}_{2} \mathrm{O}_{2}$ scavengers were found to significantly inhibit the degradation of chitosan, compared to that of ${ }^{\bullet} \mathrm{OH}$ scavenging. This might be because when ${ }^{\circ} \mathrm{O}$ and $\mathrm{H}_{2} \mathrm{O}_{2}$ were scavenged, it might enhance consumption and lower the production of ${ }^{\bullet} \mathrm{OH}$, respectively.

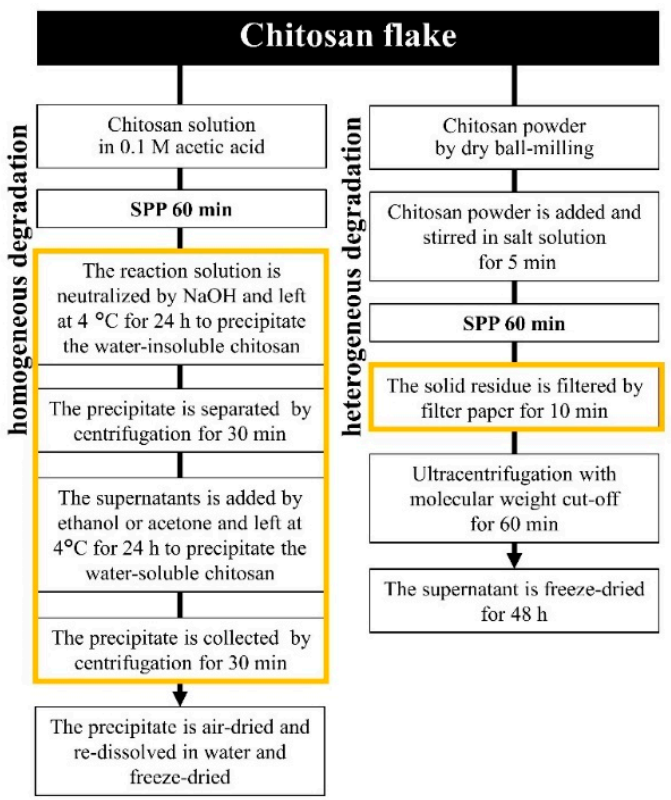

Figure 14. Flow chart of comparison between homogeneous and heterogeneous degradation of chitosan by the SPP $[39,74]$.

(a)
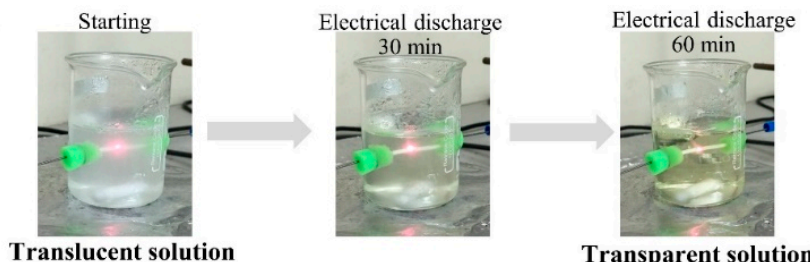

(b)
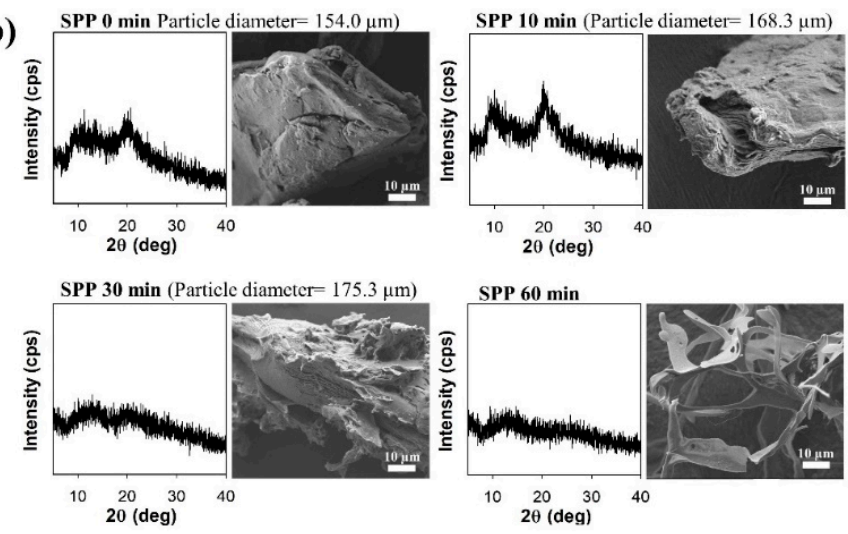

Figure 15. Cont. 


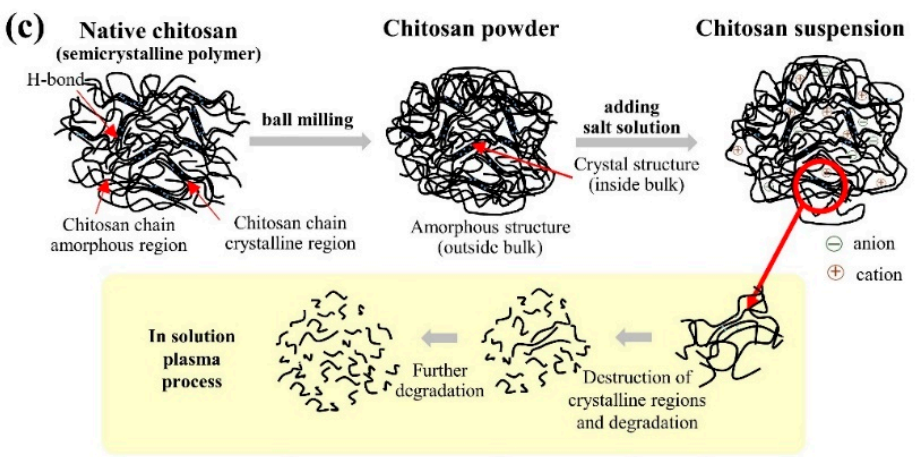

Figure 15. (a) Digital images of chitosan powder degradation by the SPP, (b) XRD and SEM results of the obtained products from chitosan powder degradation by the solution plasma process, and (c) Proposed destruction and degradation mechanism [39].

\subsection{Deacetylation of Chitin Via SPP}

Deacetylation is considered as a first step to functionalize chitin, which normally cannot dissolve in water and organic solvents, into other various derivates (e.g., chitosan). For several decades, the deacetylation of chitin converting an acetamido group at the C-2 position of a pyranose ring to an amino group has widely been conducted by conventional heat treatment $\left(100-160{ }^{\circ} \mathrm{C}\right)$ using $40-50 \% \mathrm{NaOH}$, especially in commercial scale. For example, Kurita et al. used $50 \% \mathrm{NaOH}$ solution at $130{ }^{\circ} \mathrm{C}$ [110], and Galed et al. used the corresponding concentration of $\mathrm{NaOH}$ at $110^{\circ} \mathrm{C}$ to convert chitin to chitosan [111]. Recently, the SPP was introduced and could provide effective deacetylation of chitin with much lower concentration of chemicals (i.e., $1-12 \% \mathrm{NaOH}$ ) [112]. The key for this green process was the plasma-generated reactive species, including ${ }^{\bullet} \mathrm{OH}$ and ${ }^{\bullet} \mathrm{H}$. The comparison of deacetylation via conventional heat treatment and SPP is revealed in Figure 16. Chitin hydrogel was used as a starting material and dispersed in $\mathrm{NaOH} /$ methanol/water solution (i.e., $90 \%$ methanol/water solution containing $12 \% \mathrm{NaOH}$ ). During the plasma discharge, $\bullet \mathrm{OH}$ and $\bullet \mathrm{H}$ were proposed to be generated via the following reactions:

For the conventional heat treatment,

$$
\mathrm{NaOH} \rightarrow \mathrm{Na}^{+}+\mathrm{OH}^{-}
$$

For the SPP,

$$
\begin{aligned}
& \mathrm{H}_{2} \mathrm{O} \rightarrow{ }^{\bullet} \mathrm{OH}+{ }^{\bullet} \mathrm{H} \\
& \mathrm{ROH} \rightarrow{ }^{\bullet} \mathrm{R}+{ }^{\bullet} \mathrm{OH}
\end{aligned}
$$

After the plasma treatment for $5 \mathrm{~h}$, it was found that the degree of deacetylation changed from $35 \%$ to $78 \%$, and the molecular weight of chitin decreased from approximately $10^{6}$ to $2 \times 10^{5}$, leading to the improved solubility in diluted acetic acid (2\%) and possessing antibacterial activity. Although the degree of deacetylation of the products was still not competitive with that obtained from the conventional heat treatment with a high concentration of $\mathrm{NaOH}$, the finding in this study opened an opportunity for the further development of a more environmentally friendly process for the industrial-scale production of chitosan. 


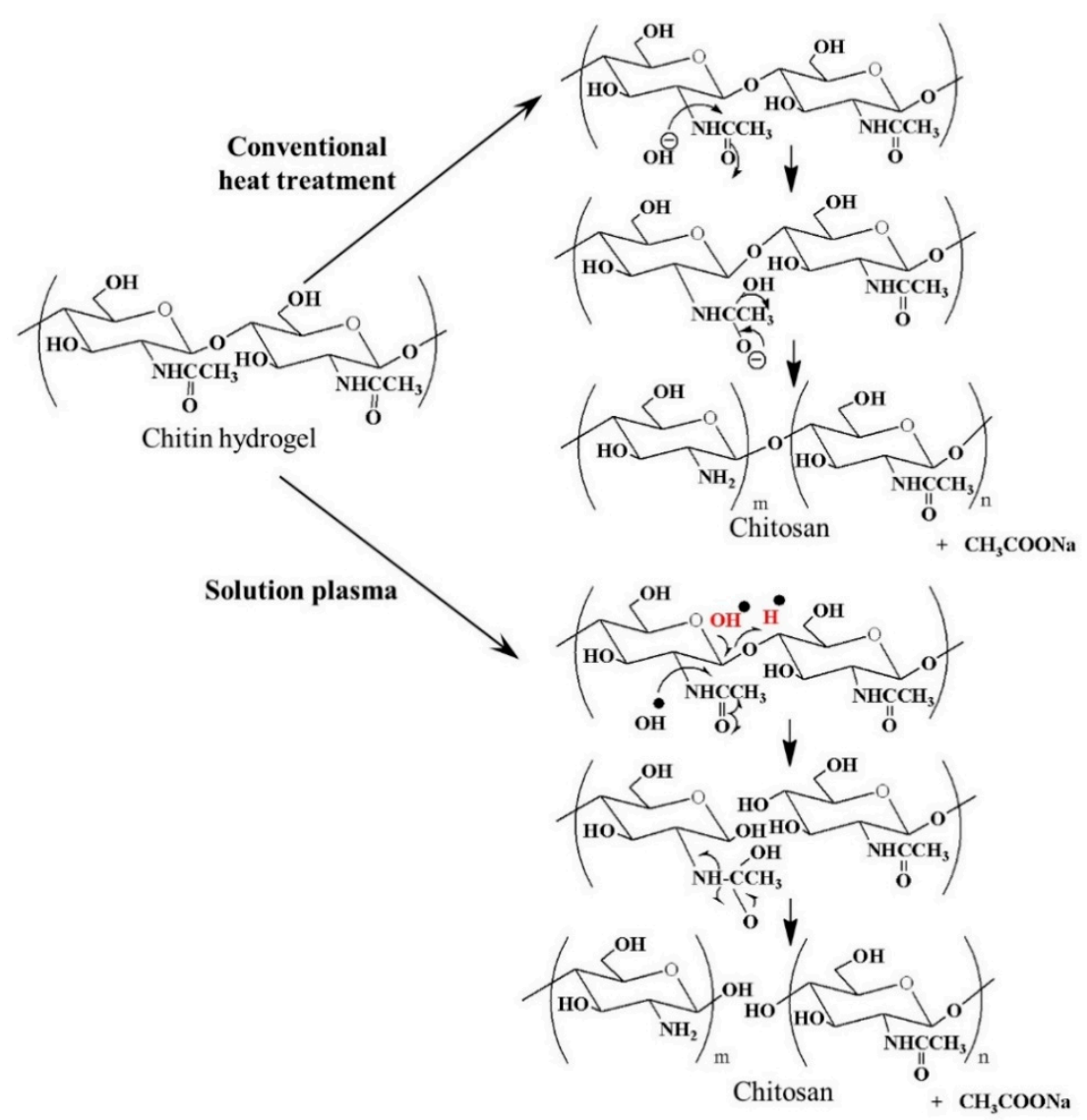

Figure 16. Comparison between deacetylations by conventional heating with $\mathrm{NaOH}(40-50 \%)$ and SPP using $\mathrm{NaOH}(1-12 \%)$ [112].

\section{Conclusions and Future Aspects}

In this paper, the fundamental electrical discharge in water and aqueous solutions using pin-to-pin electrode configuration, referred to as the solution plasma process (SPP), is discussed. A summary of parameters influencing the electrical breakdown, plasma stability, and reactive species formation is also given. The given fundamental is hoped to be used as a guideline for designing experimental setups and procedures for the SPP, aiming to obtain an effective process not only for modification of chitin and chitosan but also other kinds of application. Moreover, various strategies for the modification of chitin and chitosan, shown in this paper, update the development progress, as well as give ideas for further development to change low-value materials to high-value materials. Even though the production of high-purified chitooligosaccharides via the SPP has been accomplished, selective chain scission of chitosan and chitin to produce chitooligosaccharides with a narrow polydispersity index is challenging. Moreover, the modification of chitin and chitosan via the SPP is still in a beginning stage. It is believed that there is plenty of room to apply the SPP to modify functional groups or pyranose rings of chitin and chitosan, including deacetylation carboxylation, sulfonation, etc.

Supplementary Materials: The following are available online at https:/ /www.mdpi.com/article/10 $.3390 /$ ijms22094308/s1.

Author Contributions: C.C. wrote the manuscript; J.N. co-wrote the manuscript; G.P. and N.S. offered advice and revised the manuscript. All authors have read and agreed to the published version of the manuscript. 
Funding: This research was financially supported by the Open Innovation Platform with Enterprises, Research Institute and Academia (OPERA, Grant JPMJOP1843), and Strategic International Collaborative Research Program (SICORP, Grant JPMJSC18H1) of Japan Science and Technology Agency (JST).

Data Availability Statement: All data will be made available upon request.

Conflicts of Interest: The authors declare no conflict of interest.

\section{References}

1. Tiede, R.; Hirschberg, J.; Daeschlein, G.; Von Woedtke, T.; Vioel, W.; Emmert, S. Plasma Applications: A Dermatological View. Contrib. Plasma Phys. 2014, 54, 118-130. [CrossRef]

2. Rezaei, F.; Vanraes, P.; Nikiforov, A.; Morent, R.; De Geyter, N. Applications of Plasma-Liquid Systems: A Review. Materials 2019, 12, 2751. [CrossRef] [PubMed]

3. López, M.; Calvo, T.; Prieto, M.; Múgica-Vidal, R.; Muro-Fraguas, I.; Alba-Elías, F.; Alvarez-Ordóñez, A. A Review on Non-thermal Atmospheric Plasma for Food Preservation: Mode of Action, Determinants of Effectiveness, and Applications. Front. Microbiol. 2019, 10, 622. [CrossRef]

4. Horikoshi, S.; Serpone, N. In-liquid plasma: A novel tool in the fabrication of nanomaterials and in the treatment of wastewaters. RSC Adv. 2017, 7, 47196-47218. [CrossRef]

5. Yui, H.; Banno, M. Microspectroscopic imaging of solution plasma: How do its physical properties and chemical species evolve in atmospheric-pressure water vapor bubbles? Jpn. J. Appl. Phys. 2017, 57, 0102A1. [CrossRef]

6. Tendero, C.; Tixier, C.; Tristant, P.; Desmaison, J.; Leprince, P. Atmospheric pressure plasmas: A review. Spectrochim. Acta Part B Atomic Spectrosc. 2006, 61, 2-30. [CrossRef]

7. De Geyter, N.; Morent, R. Cold plasma surface modification of biodegradable polymer biomaterials. In Biomaterials for Bone Regeneration; Dubruel, P., Van Vlierberghe, S., Eds.; Woodhead Publishing: Cambridge, UK, 2014; pp. $202-224$.

8. Taghvaei, H.; Kheirollahivash, M.; Ghasemi, M.; Rostami, P.; Rahimpour, M.R. Noncatalytic Upgrading of Anisole in an Atmospheric DBD Plasma Reactor: Effect of Carrier Gas Type, Voltage, and Frequency. Energy Fuels 2014, 28, 2535-2543. [CrossRef]

9. Šunka, P. Pulse electrical discharges in water and their applications. Phys. Plasmas 2001, 8, 2587-2594. [CrossRef]

10. Thagard, S.M.; Takashima, K.; Mizuno, A. Plasma Chemistry in Pulsed Electrical Discharge in Liquid. Trans. Mater. Res. Soc. Jpn. 2009, 34, 257-262. [CrossRef]

11. Sato, M.; Ohgiyama, T.; Clements, J.S. Formation of chemical species and their effects on microorganisms using a pulsed high-voltage discharge in water. IEEE Trans. Ind. Appl. 1996, 32, 106-112. [CrossRef]

12. Malik, M.A.; Ghaffar, A.; Malik, S.A. Water purification by electrical discharges. Plasma Sources Sci. Technol. 2001, 10, 82-91. [CrossRef]

13. Takai, O. Solution plasma processing (SPP). Pure Appl. Chem. 2008, 80, 2003-2011. [CrossRef]

14. Hieda, J.; Saito, N.; Takai, O. Exotic shapes of gold nanoparticles synthesized using plasma in aqueous solution. J. Vac. Sci. Technol. A 2008, 26, 854. [CrossRef]

15. Janpetch, N.; Saito, N.; Rujiravanit, R. Fabrication of bacterial cellulose-ZnO composite via solution plasma process for antibacterial applications. Carbohydr. Polym. 2016, 148, 335-344. [CrossRef] [PubMed]

16. Saqib, A.N.S.; Huong, N.T.T.; Kim, S.-W.; Jung, M.-H.; Lee, Y.H. Structural and magnetic properties of highly Fe-doped ZnO nanoparticles synthesized by one-step solution plasma process. J. Alloy. Compd. 2021, 853, 157153. [CrossRef]

17. Kim, K.; Hashimi, K.; Bratescu, M.A.; Saito, N. The Initial Reactions from Pyridine to Hetero-Carbon Nanomaterials Through Solution Plasma. Nanosci. Nanotechnol. Lett. 2018, 10, 814-819. [CrossRef]

18. Kang, J.; Li, O.L.; Saito, N. A simple synthesis method for nano-metal catalyst supported on mesoporous carbon: The solution plasma process. Nanoscale 2013, 5, 6874-6882. [CrossRef]

19. Li, O.L.; Chiba, S.; Wada, Y.; Panomsuwan, G.; Ishizaki, T. Synthesis of graphitic-N and amino-N in nitrogen-doped carbon via a solution plasma process and exploration of their synergic effect for advanced oxygen reduction reaction. J. Mater. Chem. A 2017, 5, 2073-2082. [CrossRef]

20. Kang, J.; Li, O.L.; Saito, N. Synthesis of structure-controlled carbon nano spheres by solution plasma process. Carbon 2013, 60, 292-298. [CrossRef]

21. Prasertsung, I.; Chutinate, P.; Watthanaphanit, A.; Saito, N.; Damrongsakkul, S. Conversion of cellulose into reducing sugar by solution plasma process (SPP). Carbohydr. Polym. 2017, 172, 230-236. [CrossRef]

22. Davoodbasha, M.; Kim, S.-C.; Lee, S.-Y.; Kim, J.-W. The facile synthesis of chitosan-based silver nano-biocomposites via a solution plasma process and their potential antimicrobial efficacy. Arch. Biochem. Biophys. 2016, 605, 49-58. [CrossRef] [PubMed]

23. Sulaimankulova, S.; Mametova, A.; Abdullaeva, Z. Fusiform gold nanoparticles by pulsed plasma in liquid method. Sn Appl. Sci. 2019, 1, 1427. [CrossRef] 
24. Yoshimura, M.; Senthilnathan, J. Submerged Liquid Plasma for the Formation of Nanostructured Carbon. In Carbon-related Materials in Recognition of Nobel Lectures by Prof. Akira Suzuki in ICCE; Kaneko, S., Mele, P., Endo, T., Tsuchiya, T., Tanaka, K., Yoshimura, M., Hui, D., Eds.; Springer International Publishing: Cham, Switzerland, 2017; pp. 61-78.

25. Senthilnathan, J.; Rao, K.S.; Yoshimura, M. Submerged liquid plasma-Low energy synthesis of nitrogen-doped graphene for electrochemical applications. J. Mater. Chem. A 2014, 2, 3332-3337. [CrossRef]

26. Yu, F.; Wang, C.; Li, Y.; Ma, H.; Wang, R.; Liu, Y.; Suzuki, N.; Terashima, C.; Ohtani, B.; Ochiai, T.; et al. Enhanced Solar Photothermal Catalysis over Solution Plasma Activated TiO2. Adv. Sci. 2020, 7, 2000204. [CrossRef] [PubMed]

27. Panomsuwan, G.; Saito, N.; Ishizaki, T. Electrocatalytic oxygen reduction on nitrogen-doped carbon nanoparticles derived from cyano-aromatic molecules via a solution plasma approach. Carbon 2016, 98, 411-420. [CrossRef]

28. Saito, N.; Hieda, J.; Takai, O. Synthesis process of gold nanoparticles in solution plasma. Thin Solid Film. 2009, 518, 912-917. [CrossRef]

29. Pootawang, P.; Saito, N.; Takai, O. Ag nanoparticle incorporation in mesoporous silica synthesized by solution plasma and their catalysis for oleic acid hydrogenation. Mater. Lett. 2011, 65, 1037-1040. [CrossRef]

30. Pootawang, P.; Saito, N.; Lee, S.Y. Discharge time dependence of a solution plasma process for colloidal copper nanoparticle synthesis and particle characteristics. Nanotechnology 2013, 24, 055604. [CrossRef]

31. Hu, X.; Shen, X.; Takai, O.; Saito, N. Facile fabrication of PtAu alloy clusters using solution plasma sputtering and their electrocatalytic activity. J. Alloy. Compd. 2013, 552, 351-355. [CrossRef]

32. Watthanaphanit, A.; Panomsuwan, G.; Saito, N. A novel one-step synthesis of gold nanoparticles in an alginate gel matrix by solution plasma sputtering. RSC Adv. 2014, 4, 1622-1629. [CrossRef]

33. Chokradjaroen, C.; Kato, S.; Fujiwara, K.; Watanabe, H.; Ishii, T.; Ishizaki, T. A comparative study of undoped, boron-doped, and boron/fluorine dual-doped carbon nanoparticles obtained via solution plasma as catalysts for the oxygen reduction re-action. Sustain. Energy Fuels 2020, 4, 4570-4580. [CrossRef]

34. Ishizaki, T.; Chiba, S.; Kaneko, Y.; Panomsuwan, G. Electrocatalytic activity for the oxygen reduction reaction of oxy-gencontaining nanocarbon synthesized by solution plasma. J. Mater. Chem. A 2014, 2, 10589-10598. [CrossRef]

35. Morishita, T.; Ueno, T.; Panomsuwan, G.; Hieda, J.; Yoshida, A.; Bratescu, M.A.; Saito, N. Fastest Formation Routes of Nanocarbons in Solution Plasma Processes. Sci. Rep. 2016, 6, 36880. [CrossRef] [PubMed]

36. Panomsuwan, G.; Saito, N.; Ishizaki, T. Fe-N-doped carbon-based composite as an efficient and durable electrocatalyst for the oxygen reduction reaction. RSC Adv. 2016, 6, 114553-114559. [CrossRef]

37. Panomsuwan, G.; Chantaramethakul, J.; Chokradjaroen, C.; Ishizaki, T. In situ solution plasma synthesis of silver nanopar-ticles supported on nitrogen-doped carbons with enhanced oxygen reduction activity. Mater. Lett. 2019, 251, 135-139. [CrossRef]

38. Phan, P.Q.; Naraprawatphong, R.; Pornaroontham, P.; Park, J.; Chokradjaroen, C.; Saito, N. N-Doped few-layer graphene encapsulated Pt-based bimetallic nanoparticles via solution plasma as an efficient oxygen catalyst for the oxygen reduction reaction. Mater. Adv. 2021, 2, 322-335. [CrossRef]

39. Chokradjaroen, C.; Theeramunkong, S.; Yui, H.; Saito, N.; Rujiravanit, R. Cytotoxicity against cancer cells of chitosan oli-gosaccharides prepared from chitosan powder degraded by electrical discharge plasma. Carbohydr. Polym. 2018, 201, 20-30. [CrossRef]

40. Prasertsung, I.; Damrongsakkul, S.; Saito, N. Degradation of $\beta$-chitosan by solution plasma process (SPP). Polym. Degrad. Stab. 2013, 98, 2089-2093. [CrossRef]

41. Pornsunthorntawee, O.; Katepetch, C.; Vanichvattanadecha, C.; Saito, N.; Rujiravanit, R. Depolymerization of chitosan-metal complexes via a solution plasma technique. Carbohydr. Polym. 2014, 102, 504-512. [CrossRef]

42. Watthanaphanit, A.; Saito, N. Effect of polymer concentration on the depolymerization of sodium alginate by the solution plasma process. Polym. Degrad. Stab. 2013, 98, 1072-1080. [CrossRef]

43. Zalikhanov, B.Z. From an electron avalanche to the lightning discharge. Phys. Part Nucl. 2016, 47, 108-133. [CrossRef]

44. Saito, N.; Bratescu, M.A.; Hashimi, K. Solution plasma: A new reaction field for nanomaterials synthesis. Jpn. J. Appl. Phys. 2017, 57, 0102A4. [CrossRef]

45. Heo, Y.K.; Lee, S.H.; Bratescu, M.A.; Kim, S.M.; Lee, G.-J.; Saito, N. Generation of non-equilibrium condition in solution plasma discharge using low-pass filter circuit. Plasma Process. Polym. 2017, 14, 1600163. [CrossRef]

46. Prasertsung, I.; Damrongsakkul, S.; Terashima, C.; Saito, N.; Takai, O. Preparation of low molecular weight chitosan using solution plasma system. Carbohydr. Polym. 2012, 87, 2745-2749. [CrossRef]

47. Tantiplapol, T.; Singsawat, Y.; Narongsil, N.; Damrongsakkul, S.; Saito, N.; Prasertsung, I. Influences of solution plasma conditions on degradation rate and properties of chitosan. Innov. Food Sci. Emerg. Technol. 2015, 32, 116-120. [CrossRef]

48. Davoodbasha, M.; Lee, S.-Y.; Kim, J.-W. Solution plasma mediated formation of low molecular weight chitosan and its ap-plication as a biomaterial. Int. J. Biol. Macromol. 2018, 118, 1511-1517. [CrossRef] [PubMed]

49. Chokradjaroen, C.; Rujiravanit, R.; Theeramunkong, S.; Saito, N. Effect of electrical discharge plasma on cytotoxicity against cancer cells of N,O-carboxymethyl chitosan-stabilized gold nanoparticles. Carbohydr. Polym. 2020, 237, 116162. [CrossRef]

50. Potocký, Š.; Saito, N.; Takai, O. Needle electrode erosion in water plasma discharge. Thin Solid Film. 2009, 518, 918-923. [CrossRef] 
51. Hayashi, Y.; Takada, N.; Wahyudiono; Kanda, H.; Goto, M. Hydrogen Peroxide Formation by Electric Discharge with Fine Bubbles. Plasma Chem. Plasma Process. 2017, 37, 125-135. [CrossRef]

52. Mai-Prochnow, A.; Zhou, R.; Zhang, T.; Ostrikov, K.; Mugunthan, S.; Rice, S.A.; Cullen, P.J. Interactions of plasma-activated water with biofilms: Inactivation, dispersal effects and mechanisms of action. NPJ Biofilms Microbiomes 2021, 7, 1-12. [CrossRef]

53. Tanioka, S.; Matsui, Y.; Irie, T.; Tanigawa, T.; Tanaka, Y.; Shibata, H.; Sawa, Y.; Kono, Y. Oxidative Depolymerization of Chitosan by Hydroxyl Radical. Biosci. Biotechnol. Biochem. 1996, 60, 2001-2004. [CrossRef]

54. Miron, C.; Bratescu, M.A.; Saito, N.; Takai, O. Optical diagnostic of bipolar electrical discharges in $\mathrm{HCl}, \mathrm{KCl}$, and $\mathrm{KOH}$ solutions. J. Appl. Phys. 2011, 109, 123301. [CrossRef]

55. Langendorf, S.; Walker, M. Effect of secondary electron emission on the plasma sheath. Phys. Plasmas 2015, 22, 033515. [CrossRef]

56. Magnusson, J.M.; Collins, A.L.; Wirz, R.E.; Magnusson, J. Polyatomic Ion-Induced Electron Emission (IIEE) in Electrospray Thrusters. Aerospace 2020, 7, 153. [CrossRef]

57. Phan, P.Q.; Chae, S.; Pornaroontham, P.; Muta, Y.; Kim, K.; Wang, X.; Saito, N. In situ synthesis of copper nanoparticles encapsulated by nitrogen-doped graphene at room temperature via solution plasma. RSC Adv. 2020, 10, 36627-36635. [CrossRef]

58. Wang, H.; Wandell, R.J.; Tachibana, K.; Voráč, J.; Locke, B.R. The influence of liquid conductivity on electrical breakdown and hydrogen peroxide production in a nanosecond pulsed plasma discharge generated in a water-film plasma reactor. J. Phys. $D$ Appl. Phys. 2018, 52, 075201. [CrossRef]

59. Takeuchi, N.; Kawahara, K.; Gamou, F.; Li, O.L.H. Observation of solution plasma in water-ethanol mixed solution for reduction of graphene oxide. Int. J. Plasma Environ. Sci. Technol. 2020, 14, e01009.

60. Schmieder, F. Neue Wirkungsquerschnittsmessungen an Gasen und Dämpfen. Z Elektrochem Angeww P 1930, 36, 700-704.

61. Szmytkowski, C.; Możejko, P. Electron-scattering total cross sections for triatomic molecules: $\mathrm{NO}_{2}$ and $\mathrm{H}_{2} \mathrm{O}$. Opt. Appl. 2006, 36, 543-550.

62. Panomsuwan, G.; Chokradjaroen, C.; Rujiravanit, R.; Ueno, T.; Saito, N. In vitro cytotoxicity of carbon black nanoparticles synthesized from solution plasma on human lung fibroblast cells. Jpn. J. Appl. Phys. 2018, 57, 0102BG. [CrossRef]

63. Miron, C.; Bratescu, M.A.; Saito, N.; Takai, O.; Brătescu, M.A. Time-resolved Optical Emission Spectroscopy in Water Electrical Discharges. Plasma Chem. Plasma Process. 2010, 30, 619-631. [CrossRef]

64. Miron, C.; Bratescu, M.; Saito, N.; Takai, O. Effect of the electrode work function on the water plasma breakdown voltage. Curr. Appl. Phys. 2011, 11, S154-S158. [CrossRef]

65. Banno, M.; Kanno, K.; Yui, H. Development of direct gas injection system for atmospheric-pressure in-solution discharge plasma for plasma degradation and material syntheses. RSC Adv. 2016, 6, 16030-16036. [CrossRef]

66. Kim, S.-K. Chitin, Chitosan, Oligosaccharides and Their Derivatives: Biological Activities and Applications; CRC Press: Boca Raton, FL, USA, 2010.

67. Kumar, M.N.R. A review of chitin and chitosan applications. React. Funct. Polym. 2000, 46, 1-27. [CrossRef]

68. Rinaudo, M. Chitin and chitosan: Properties and applications. Prog. Polym. Sci. 2006, 31, 603-632. [CrossRef]

69. Kaczmarek, M.B.; Struszczyk-Swita, K.; Li, X.; Szczęsna-Antczak, M.; Daroch, M. Enzymatic Modifications of Chitin, Chitosan, and Chitooligosaccharides. Front. Bioeng. Biotechnol. 2019, 7, 243. [CrossRef] [PubMed]

70. Kumar, A.V.; Tharanathan, R. A comparative study on depolymerization of chitosan by proteolytic enzymes. Carbohydr. Polym. 2004, 58, 275-283.

71. Xia, W.; Liu, P.; Zhang, J.; Chen, J. Biological activities of chitosan and chitooligosaccharides. Food Hydrocoll. 2011, 25, 170-179. [CrossRef]

72. Merzendorfer, H.; Cohen, E. Chitin/Chitosan: Versatile Ecological, Industrial, and Biomedical Applications. In Extracellular Sugar-Based Biopolymers Matrices; Cohen, E., Merzendorfer, H., Eds.; Springer International Publishing: Cham, Switzerland, 2019; pp. 541-624.

73. Pillai, C.; Paul, W.; Sharma, C.P. Chitin and chitosan polymers: Chemistry, solubility and fiber formation. Prog. Polym. Sci. 2009, 34, 641-678. [CrossRef]

74. Chokradjaroen, C.; Rujiravanit, R.; Watthanaphanit, A.; Theeramunkong, S.; Saito, N.; Yamashita, K.; Arakawa, R. Enhanced degradation of chitosan by applying plasma treatment in combination with oxidizing agents for potential use as an anticancer agent. Carbohydr. Polym. 2017, 167, 1-11. [CrossRef] [PubMed]

75. Liu, J.; Zhang, J.; Xia, W. Hypocholesterolaemic effects of different chitosan samples in vitro and in vivo. Food Chem. 2008, 107, 419-425. [CrossRef]

76. No, H.K.; Park, N.Y.; Lee, S.H.; Meyers, S.P. Antibacterial activity of chitosans and chitosan oligomers with different molecular weights. Int. J. Food Microbiol. 2002, 74, 65-72. [CrossRef]

77. Lee, S.-H.; Senevirathne, M.; Ahn, C.-B.; Kim, S.-K.; Je, J.-Y. Factors affecting anti-inflammatory effect of chitooligosaccharides in lipopolysaccharides-induced RAW264.7 macrophage cells. Bioorg. Med. Chem. Lett. 2009, 19, 6655-6658. [CrossRef]

78. Prashanth, K.H.; Tharanathan, R. Depolymerized products of chitosan as potent inhibitors of tumor-induced angiogenesis. Biochim. Biophys. Acta (Bba) Gen. Subj. 2005, 1722, 22-29. [CrossRef] [PubMed]

79. Vo, T.-S.; Kong, C.-S.; Kim, S.-K. Inhibitory effects of chitooligosaccharides on degranulation and cytokine generation in rat basophilic leukemia RBL-2H3 cells. Carbohydr. Polym. 2011, 84, 649-655. [CrossRef] 
80. Jung, W.-K.; Moon, S.-H.; Kim, S.-K. Effect of chitooligosaccharides on calcium bioavailability and bone strength in ovariectomized rats. Life Sci. 2006, 78, 970-976. [CrossRef] [PubMed]

81. Feng, T.; Du, Y.; Li, J.; Hu, Y.; Kennedy, J.F. Enhancement of antioxidant activity of chitosan by irradiation. Carbohydr. Polym. 2008, 73, 126-132. [CrossRef]

82. Einbu, A.; Grasdalen, H.; Vårum, K.M. Kinetics of hydrolysis of chitin/chitosan oligomers in concentrated hydrochloric acid. Carbohydr. Res. 2007, 342, 1055-1062. [CrossRef]

83. Vårum, K.; Ottøy, M.; Smidsrød, O. Acid hydrolysis of chitosans. Carbohydr. Polym. 2001, 46, 89-98. [CrossRef]

84. Kim, S.; Rajapakse, N. Enzymatic production and biological activities of chitosan oligosaccharides (COS): A review. Carbohydr. Polym. 2005, 62, 357-368. [CrossRef]

85. Cabrera, J.C.; Van Cutsem, P. Preparation of chitooligosaccharides with degree of polymerization higher than 6 by acid or enzymatic degradation of chitosan. Biochem. Eng. J. 2005, 25, 165-172. [CrossRef]

86. Shao, J.; Yang, Y.; Zhong, Q. Studies on preparation of oligoglucosamine by oxidative degradation under microwave irra-diation. Polym. Degrad. Stab. 2003, 82, 395-398. [CrossRef]

87. Wasikiewicz, J.M.; Yeates, S.G. “Green” molecular weight degradation of chitosan using microwave irradiation. Polym. Degrad. Stab. 2013, 98, 863-867. [CrossRef]

88. Wasikiewicz, J.M.; Yoshii, F.; Nagasawa, N.; Wach, R.A.; Mitomo, H. Degradation of chitosan and sodium alginate by gamma radiation, sonochemical and ultraviolet methods. Radiat. Phys. Chem. 2005, 73, 287-295. [CrossRef]

89. Poshina, D.N.; Raik, S.V.; Poshin, A.N.; Skorik, Y.A. Accessibility of chitin and chitosan in enzymatic hydrolysis: A review. Polym. Degrad. Stab. 2018, 156, 269-278. [CrossRef]

90. Choi, W.-S.; Ahn, K.-J.; Lee, D.-W.; Byun, M.-W.; Park, H.-J. Preparation of chitosan oligomers by irradiation. Polym. Degrad. Stab. 2002, 78, 533-538. [CrossRef]

91. Savitri, E.; Juliastuti, S.R.; Handaratri, A.; Sumarno; Roesyadi, A. Degradation of chitosan by sonication in very-low-concentration acetic acid. Polym. Degrad. Stab. 2014, 110, 344-352. [CrossRef]

92. Li, K.; Xing, R.; Liu, S.; Qin, Y.; Meng, X.; Li, P. Microwave-assisted degradation of chitosan for a possible use in inhibiting crop pathogenic fungi. Int. J. Biol. Macromol. 2012, 51, 767-773. [CrossRef]

93. Domard, A.; Cartier, N. Glucosamine oligomers: 1. Preparation and characterization. Int. J. Biol. Macromol. 1989, 11, 297-302. [CrossRef]

94. Ngo, D.-N.; Lee, S.-H.; Kim, M.-M.; Kim, S.-K. Production of chitin oligosaccharides with different molecular weights and their antioxidant effect in RAW 264.7 cells. J. Funct. Foods 2009, 1, 188-198. [CrossRef]

95. Furusaki, E.; Ueno, Y.; Sakairi, N.; Nishi, N.; Tokura, S. Facile preparation and inclusion ability of a chitosan derivative bearing carboxymethyl- $\beta$-cyclodextrin. Carbohydr. Polym. 1996, 29, 29-34. [CrossRef]

96. Defaye, J.; Gadelle, A.; Pedersen, C. A convenient access to $\beta$-(1 $\rightarrow$ 4)-linked 2-amino-2-deoxy-d-glucopyranosyl fluoride oligosaccharides and $\beta$-(1 $\rightarrow$ 4)-linked 2-amino-2-deoxy-d-glucopyranosyl oligosaccharides by fluorolysis and fluorohy-drolysis of chitosan. Carbohydr. Res. 1994, 261, 267-277. [CrossRef]

97. Tian, F.; Liu, Y.; Hu, K.; Zhao, B. Study of the depolymerization behavior of chitosan by hydrogen peroxide. Carbohydr. Polym. 2004, 57, 31-37. [CrossRef]

98. Fukamizo, T.; Honda, Y.; Goto, S.; Boucher, I.; Brzezinski, R. Reaction mechanism of chitosanase from Streptomyces sp. N174. Biochem. J. 1995, 311, 377-383. [CrossRef]

99. Yoon, J.H. Enzymatic synthesis of chitooligosaccharides in organic cosolvents. Enzym. Microb. Technol. 2005, 37, 663-668. [CrossRef]

100. Lin, H.; Wang, H.; Xue, C.; Ye, M. Preparation of chitosan oligomers by immobilized papain. Enzym. Microb. Technol. 2002, 31, 588-592. [CrossRef]

101. Xing, R.; Liu, S.; Yu, H.; Guo, Z.; Wang, P.; Li, C.; Li, Z.; Li, P. Salt-assisted acid hydrolysis of chitosan to oligomers under microwave irradiation. Carbohydr. Res. 2005, 340, 2150-2153. [CrossRef]

102. Kang, B.; Dai, Y.-D.; Zhang, H.-Q.; Chen, D. Synergetic degradation of chitosan with gamma radiation and hydrogen peroxide. Polym. Degrad. Stab. 2007, 92, 359-362. [CrossRef]

103. Huang, Y.; Wang, P.; Yuan, Y.; Ren, X.; Yang, F. Synergistic degradation of chitosan by impinging stream and jet cavitation. Ultrason. Sonochem. 2015, 27, 592-601. [CrossRef]

104. Yan, J.; Ai, S.; Yang, F.; Zhang, K.; Huang, Y. Study on mechanism of chitosan degradation with hydrodynamic cavitation. Ultrason. Sonochem. 2020, 64, 105046. [CrossRef] [PubMed]

105. Ma, F.; Wang, Z.; Zhao, H.; Tian, S. Plasma Depolymerization of Chitosan in the Presence of Hydrogen Peroxide. Int. J. Mol. Sci. 2012, 13, 7788-7797. [CrossRef] [PubMed]

106. Chokradjaroen, C.; Rujiravanit, R.; Theeramunkong, S.; Saito, N. Degradation of chitosan hydrogel dispersed in dilute carboxylic acids by solution plasma and evaluation of anticancer activity of degraded products. Jpn J. Appl. Phys. 2018, 57, 0102B5. [CrossRef]

107. Ma, F.; Li, P.; Zhang, B.; Zhao, X.; Fu, Q.; Wang, Z.; Gu, C. Effect of solution plasma process with bubbling gas on physico-chemical properties of chitosan. Int. J. Biol. Macromol. 2017, 98, 201-207. [CrossRef]

108. Skonberg, C.; Olsen, J.; Madsen, K.G.; Hansen, S.H.; Grillo, M.P.; Olsen, J. Metabolic activation of carboxylic acids. Expert Opin. Drug Metab. Toxicol. 2008, 4, 425-438. [CrossRef] [PubMed] 
109. Ma, F.; Zhang, S.; Li, P.; Sun, B.; Xu, Y.; Tao, D.; Zhao, H.; Cui, S.; Zhu, R.; Zhang, B. Investigation on the role of the free radicals and the controlled degradation of chitosan under solution plasma process based on radical scavengers. Carbohydr. Polym. 2021, 257, 117567. [CrossRef] [PubMed]

110. Kurita, K.; Kamiya, M.; Nishimura, S.-I. Solubilization of a rigid polysaccharide: Controlled partial N-Acetylation of chitosan to develop solubility. Carbohydr. Polym. 1991, 16, 83-92. [CrossRef]

111. Galed, G.; Miralles, B.; Paños, I.; Santiago, A.; Heras, Á. N-Deacetylation and depolymerization reactions of chitin/chitosan: Influence of the source of chitin. Carbohydr. Polym. 2005, 62, 316-320. [CrossRef]

112. Rujiravanit, R.; Kantakanun, M.; Chokradjaroen, C.; Vanichvattanadecha, C.; Saito, N. Simultaneous deacetylation and degradation of chitin hydrogel by electrical discharge plasma using low sodium hydroxide concentrations. Carbohydr. Polym. 2020, 228, 115377. [CrossRef] 